\title{
Tightening the thread from seed to cloth. New enquiries in the archaeology of old World cotton
}

A case for inter-disciplinarity

Tendre un fil de la graine à l'habit. Nouvelles recherches sur l'archéologie du coton dans l'Ancien Monde : l'apport de l'interdisciplinarité

Charlène Bouchaud, Elsa Yvanez and John Peter Wild

\section{OpenEdition}

Journals

Electronic version

URL: http://journals.openedition.org/ethnoecologie/4501

DOI: 10.4000/ethnoecologie.4501

ISSN: 2267-2419

\section{Publisher}

Laboratoire Eco-anthropologie et Ethnobiologie

\section{Electronic reference}

Charlène Bouchaud, Elsa Yvanez and John Peter Wild, «Tightening the thread from seed to cloth. New enquiries in the archaeology of Old World cotton », Revue d'ethnoécologie [Online], 15 | 2019, Online since 30 June 2019, connection on 23 December 2019. URL : http://journals.openedition.org/ ethnoecologie/4501; DOI : 10.4000/ethnoecologie.4501

This text was automatically generated on 23 December 2019.

\section{c) (†) $\odot$}

Revue d'ethnoécologie est mis à disposition selon les termes de la licence Creative Commons Attribution - Pas d'Utilisation Commerciale - Pas de Modification 4.0 International. 


\section{Tightening the thread from seed to cloth. New enquiries in the archaeology of old World cotton}

A case for inter-disciplinarity

Tendre un fil de la graine à l'habit. Nouvelles recherches sur l'archéologie du coton dans l'Ancien Monde : l'apport de l'interdisciplinarité

Charlène Bouchaud, Elsa Yvanez and John Peter Wild

« Un homme qui passe remarque un arbuste dont les branches se terminent par des flocons blancs. On peut imaginer qu'il approche la main. L'espèce humaine vient de faire connaissance avec la douceur du coton. " « Pour comprendre les mondialisations, celles

d'hier et celle d'aujourd'hui, rien ne vaut l'examen d'un morceau de tissu. Sans doute parce qu'il n'est fait que de fils et de liens, et des voyages de la navette. ${ }^{1}$

Erik Orsenna 2006 - Voyage au pays du coton, 11-12,

\section{Introduction}

1 In these two powerful sentences, the French academician Erik Orsenna encapsulates the essence of our approach: studying the development of cotton production as a raw resource for the textile industry, highlighting cotton's attractiveness since the very beginnings of textile production and its significant societal impact. The articles gathered in this volume will illustrate the key position of cotton in the industrial and 
economic lives of past populations, from $1^{\text {st }}$ millennium BCE Mesopotamia to colonial Sub-Saharan Africa.

2 Today, cotton (Gossypium sp.) is an eloquent symbol of modern globalisation, conjuring images of both a soft sweater and social and environmental disasters. Its internationalisation, however, is not the result of a recent process: the history of cotton and its four domesticated species shows one of the most outstanding examples of social, environmental, technical and economic entanglement. The various trajectories of cotton products, raw and processed seeds and fibres, are relevant markers of the circulation of knowledge, goods and people. Cotton is a perfect case study for Global History requiring the convergence of different points of view. With this aim in mind, the present publication results from a collaborative meeting organised at the National Museum of Natural History ${ }^{2}$, Paris, on the $3^{\text {rd }}$ and $4^{\text {th }}$ of May 2017 (https:// gossypium.sciencesconf.org/). The conference brought together researchers coming from different scientific fields, such as agronomy, anthropology, archaeobotany, genetic, geochemistry, history, archaeology, linguistics, and textile studies, all sharing a common interest in cotton. Our objective was to review the current state of our knowledge on the domestication, the emergence and the diffusion of the cotton plant and its various products - fibres, seeds, oil, textiles, etc. - in order to highlight the recent research, its current issues and future challenges. This meeting focused on cultivated cottons in the Old World ${ }^{3}$, especially in the Indian subcontinent, south-west Asia, Africa and the Mediterranean (Gossypium herbaceum and Gossypium arboreum), while considering studies, methods and protocols developed for American cottons (Gossypium barbadense, Gossypium hirsutum). The large chronological and geographical framework of the conference, and of the resulting articles in this volume, allows for the perception and understanding of the long term dynamics that raised cotton from a tropical wild plant to a valuable crop at the heart of past and modern agriculture and economics. Sustained by a growing demand, the cultivation of cotton soon became supported by ancient official institutions and required a larger workforce (Fuller 2014 and conference paper). If the question of domestication has long dominated the debate, the papers presented during the conference showed the extraordinary influence of past cotton cultivation in the transformation of the landscape, agricultural calendar, trade patterns and clothing habits.

3 In this article, we wish to introduce several keys of understanding - factual as well as methodological - that the reader might wish to keep in mind through the exploration of past cottons. Special attention will be devoted to the establishment of cotton's chaine opératoire, to reconstruct the successive technical steps transforming the plant and its fibres into a range of sought-after products. Drawing on the potential of multi- and inter-disciplinary studies, each type of sources pertaining to cotton production in the old World will be briefly presented and evaluated. The following papers will then offer a rich illustration of this process, focussing on one or several available sources, to reveal the dynamics of domestication and diffusion of cotton, as well as its far-reaching influences on the environment, societies, crafts, and economies of ancient populations. 


\section{From seed to cloth}

\section{Botanic definition and modern agronomic requirement}

4 Cotton belongs to the Malvaceae family and the genus Gossypium, which comprises approximately 45 herbaceous and woody perennial wild species growing at tropical and sub-tropical latitudes. Behind the apparent unity of the term "cotton" lie complex trajectories, involving four species domesticated at different times and in different parts of the world. Two species were domesticated in the Old World, G. herbaceum in Africa, and G. arboreum on the Indian subcontinent. They were supplanted from the $19^{\text {th }}$ century onwards by American cotton, which offered better qualities for textile production. Currently, the most widely used cotton is G. hirsutum, a very productive species native to Mesoamerica. The second New World species, G. barbadense, from South America (Peru), is known as "Egyptian cotton", characterised by its extra-long fibres and today produced in Egypt (Brubaker et al. 1999, Page et al. 2013, see also Viot, this volume, Wendel \& Cronn 2003).

Cotton relies for growth and maturation on hot and humid short days and it does not tolerate temperatures below $5^{\circ} \mathrm{C}$. Today, it is grown between the latitudes of $37^{\circ}$ north $\left(45^{\circ}\right.$ north in China) and $30^{\circ}$ south in temperate, subtropical and tropical regions. The cotton plant is a perennial small tree but has been progressively domesticated and selected to be grown as a pseudo-annual shrub (Figures 1, 2 and 3). Present-day varieties grow $25 \mathrm{~cm}$ to over $2 \mathrm{~m}$ high, depending on cultivation methods. From sowing to harvesting, the growing cycle, lasts between 160 and 210 days (depending on varieties, local climate and growing conditions), during which time optimal temperatures must be higher than $15^{\circ} \mathrm{C}$. Cotton also requires a significant supply of water at the beginning of the season, followed by dry conditions during the last two months of maturation. In the northern hemisphere, cotton therefore grows and matures during summer. This seasonality differentiates cotton from the plants commonly grown in these regions since the Neolithic, such as wheat, barley, and flax, which grow in winter or spring and are harvested in early summer (Chaudhry \& Guitchounts 2003, Reis et al. 2006: 49, Viot, this volume, Smith \& Cothren 1999, Stephens 1976). 
Figure 1: Perennial Gossypium arboreum, India

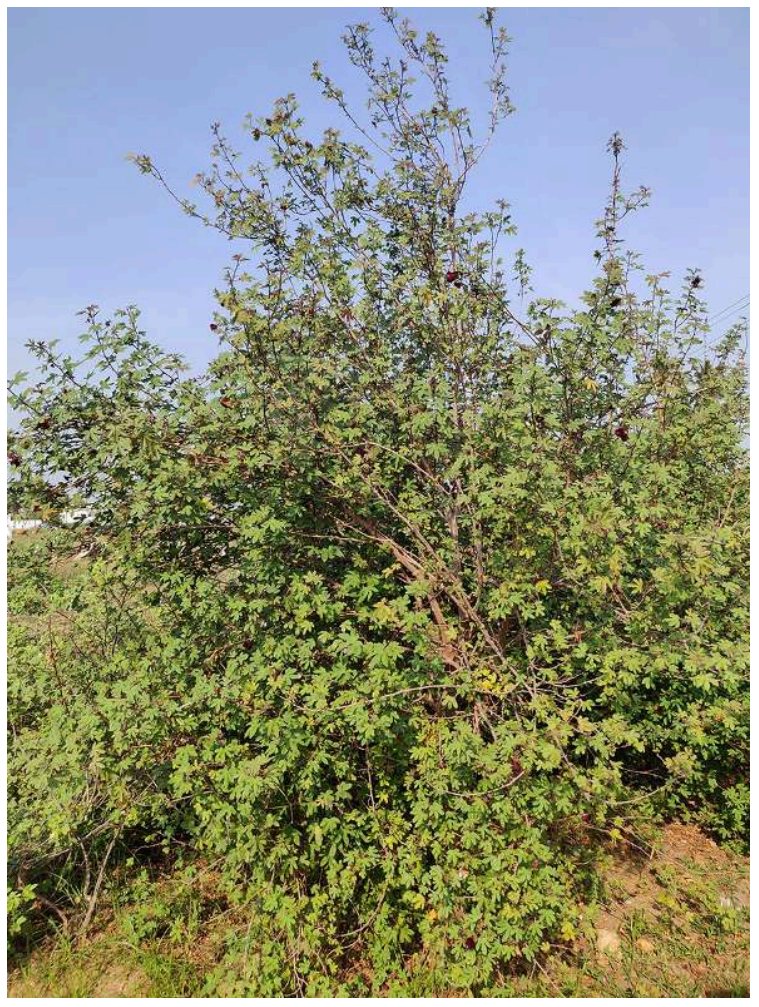

(C) Rasi Seeds company, India

Figure 2: Pseudo-annual Gossypium arboreum. Las Chapatales (Sevilla), Spain

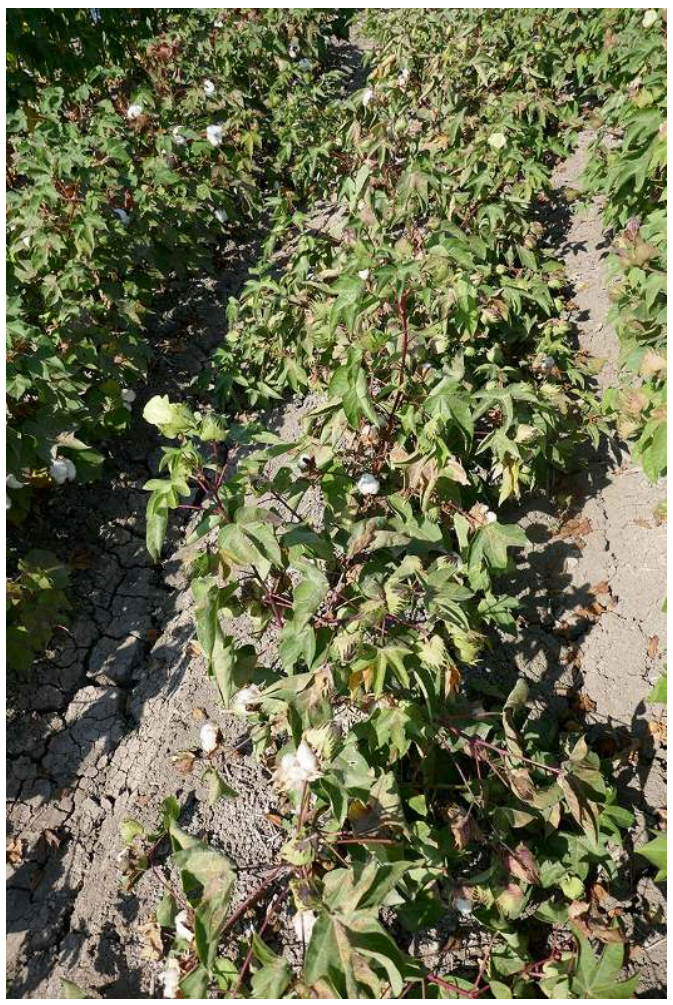

Photo C. Bouchaud 


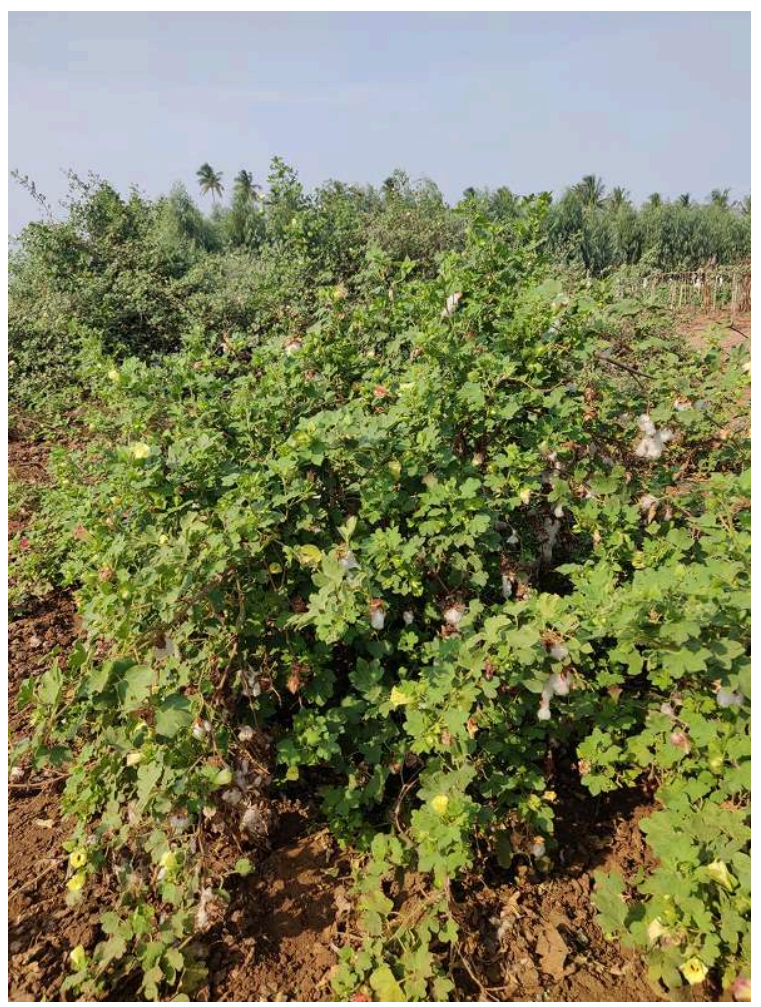

(C) Photo Rasi Seeds

\section{Old World cottons: trees or shrubs?}

6 Despite the misleading Latin name of Gossypium herbaceum and G. arboreum, which can lead to confusion about their morphology (see in particular the abusive shortcut proposed by Trombert 1996), the two species are in fact similar. They include both annual and perennial varieties, in shrub or tree forms (Figures 1,2 and 3), growing in tropical regions - where rainfed cultivation is practiced - and sub-tropical varieties where irrigation may be essential. Both are drought-resistant plants and resistant to pests. In this respect, they differ from the American species, in particular G. hirsutum, which is more water-intensive and less resistant to pest attacks. Today, the old World cottons are still exploited by small farmers in West Africa, western Egypt, India, Bangladesh, Pakistan and Iran as annual or perennial (Boulos 2000: 111, Eyhorn et al. 2005, see also recent examples in Cameroun in Seignobos, this volume).

7 Actual cotton cultivars are the result of long and complex Human selections and the present agronomic data cannot be directly used to interpret past growing conditions. The first pitfall to avoid relates to plant shape. The large number of written references mentioning "trees" or "shrubs" in different places and times shows that ancient cotton had to be widely cultivated as a perennial (able to produce such a large growing shape) rather than as an annual plant (which looks like a tall plant, or a shrublet/bush). In Mesopotamia, a written royal inscription dated to reign of the Assyrian king Sennacherib (704-681 BCE) mentions the cultivation of "trees bearing wool" in the palace of Nineveh ${ }^{4}$ ). Among the Greco-Roman literature, a number of classical authors, 
such as Herodotus $\left(5^{\text {th }}\right.$ c. BCE), Theophrastus ( $4^{\text {th }}$ c. BCE), Strabo ( $1^{\text {st }}$ c. BC- $1^{\text {st }}$ c. CE), Pliny the Elder $\left(1^{\text {st }} \mathrm{c} . \mathrm{CE}\right)$, Pomponius Mela $\left(1^{\text {st }} \mathrm{c} . \mathrm{CE}\right)$, and Arrian $\left(1^{\text {st }}-2^{\text {nd }} \mathrm{C} . \mathrm{CE}\right)$ use the same periphrasis referring to trees to designate cotton in India and Bahrein ${ }^{5}$. The existence of the Chinese ideogram mumian designating the "tree lint [silk]" is also interpreted as referring to tree cotton (Trombert 1996: 206). The first Arab botanist to mention cotton, Abū Ḥanīfa al-Dīnāwarī (c. 895 CE) wrote: "Un nomade de la tribu des Kalb m'a rapporté que le coton grandissait chez eux sous la forme d'un arbre jusqu'à atteindre la taille de l'abricotier et il reste ainsi vingt ans" ${ }^{6 "}$ (al-Dīnāwarī, Kitāa an-nabāt, ed. 1973: 217-18, ed. Muhammad Hamidullah 1973). Later, in the $12^{\text {th }}$ century, the Andalousian agronomist Ibn al-'Awwām indicated that "Dans l'Hejaz, en Égypte, à Ascalon, à Bassora (...) il atteint les proportions du figuier. Chez nous, il vit plusieurs années pendant lesquelles il fournit du coton ${ }^{7 "}$ (Ibn al-'Awwām, Kitāb al-filāḥa 2.22, ed. Clément-Mullet 1866: 102).

In addition, annual varieties have been developed over the last two millennia in several northern Mediterranean and Eurasian continental areas, where cotton, which is not frost tolerant, must be planted annually (Brite \& Marston 2013, Palmer et al. 2012). The Nabataean agriculture, a large compilation made in Iraq between the $3^{\text {rd }}$ and $5^{\text {th }}$ centuries CE and translated into Arabic in the $10^{\text {th }}$ century by Ibn Wahšiyya, indicates that cotton was cultivated as an annual plant sown in April and harvested in July (Ibn Waḩ̌iyya, Kitab al-falaha al-nabatiya, ed. Fahd 1993: 520-521). Most Arab agronomists also mention the existence of annual cotton; while others relate to the cultivation of perennial plant (see examples and references in Ducène, this volume).

\section{Cotton and water}

9 In line with our contemporary perception of cotton as a highly water-intensive crop, ancient texts report the importance of a good water supply, either through rainfall, as described by Strabo for India (Geo. 15.20), or through irrigation devices, as mentioned by several Arab agronomists (Abū l-Hुayr, Ibn Bașșāl, and Ibn Luyūn, see detailed descriptions in Ducène, this volume). Other data clearly shows that ancient cotton could endure drought conditions. Geomorphological and geoarchaeological studies conducted in Kharga and Dakhla oasis (Western Egypt), have indicated several occurrences of drought episodes and strong sand winds, accompanied by a decrease in water resources, at the same time as textual and archaeobotanical sources document local cotton cultivation (Bouchaud \& Tallet in press). The archaeogenomic analysis of cotton remains from Qasr Ibrim (Egyptian Nubia, $4^{\text {th }} \mathrm{C}$. CE) also showed the resistance of ancient cotton to a significant level of local environmental stress (Palmer et al. 2012). We should therefore consider the greater diversity of cotton growing conditions, which was already illustrated during the $12^{\text {th }}$ century CE by Ibn al-'Awwām's description of cotton cultivation in southern Spain: "Suivant Abou'l-Khaïr et autres, on cultive le coton en terrain arrosé et en terrain qui ne l'est pas. Suivant Ibn-el-Façel, la terre qui, en Espagne, convient au cotonnier, c'est la terre rude et celle qui est aride ; dans ces deux natures de terre, son produit est précoce et d'un grand profit, et jamais il n'éprouve de retard dans son époque (de maturité). Il en est qui disent que le cotonnier aime un sol frais, quand on le sème en terrain non arrosée" (Ibn al-'Awwām, Kitāb alfilăha 2.22, ed. Clément-Mullet 1866: 101). 


\section{Chaîne opératoire from harvesting to products and by-products uses}

10 As Orsenna points out in a humoristic and nevertheless true formula, "cotton is the pig of botany: in it, everything is worth taking. So everything is taken"'. Historical sources show the exploitation of every part of the plant for diverse uses, from the most precious fruit to leaves and stems. The chaine opératoire of cotton is therefore quite extensive, covering different spheres of the economy and involving different actors. It combines elements from both agriculture and textile production, with several forays into domestic life and the medical arts. In appearance, it follows a natural flow starting from the harvest, going through several processes, which allow the transformation of the raw material into several products (some of them perceived as commodities), and finishing with a range of objects with uses as diverse as a hat, an animal saddle, a cosmetic ointment, or cooking fuel. The modalities of each step is highly dependent on the cultural milieu under consideration, and their perception in the archaeological record relies on different taphonomic processes. It is nonetheless crucial to base our understanding of cotton on a sound appreciation of its complete chaîne opératoire ${ }^{10}$. While highlighting the logic of production, the resources and skills needed to move from plant to textiles with added value (Harlow \& Nosch 2014: 20-21), the extensive coverage of cotton's chaîne opératoire reflects the deep integration of cotton and textile production in every life dimensions of past societies. Studying cotton, we are reconstructing the thread that linked agricultural practices to garment and, ultimately, technology to society ${ }^{11}$.

11 The following paragraphs will highlight the different routes taken by each of cotton's raw products: the fruits, i.e. the bolls - with fibres and seeds embedded in capsules and the vegetative parts of the plant - including bracts, leaves and stems.

Our main focus will be the arguably most valuable part of the plant: its fruit. The fruit of cotton is a rigid capsule that opens at maturity in form of a boll (Figure 4) composed of oleaginous seeds surrounded by fine fibres used for textile production. Handharvesting of cotton bolls leaves behind most of the bracts that surround the bolls as well as stems and leaves, which can then be harvested separately and used as fuel (Abasaeed 1992, Gomes et al. 1997) or as fodder in small quantities for ruminants (Suttie 2004: 168) (see Figure 6). The bolls are divided into three to five loculi, each containing six to nine seeds. Two kinds of epidermal hairs (trichomes) cover the seed coat. The longest constitutes the lint, which can be easily pulled off at maturity to be spun into threads. The shortest trichomes or "fuzz" (2-7 mm long) are more difficult to remove (Figure 4) and are used today as cotton wool (Reis et al. 2006: 47). Carried out by hand until modern times, ginning aims to release the fibres from the seeds, by rolling a cylinder or a wooden stick on the bolls. Fibres are then fluffed, using a comb or a bow, or spun immediately after gently removing the lint from the seed. This last step keeps the fibres in their original order, so as to avoid the soft fluffs to be mixed up, and leads to more durable, soft, and warm fibres (Crowfoot 1924, Nicholson 1960: 14, Smolderen, this volume). From this step downwards, the general process is in many ways identical to the textile's chaine opératoire ${ }^{12}$. 
Figure 4: Gossypium arboreum, Las Chapatales (Sevilla), Spain. (A) Cotton fruit: immature (right) and mature (left). (B) Modern cotton seed after ginning process, with short fibres ("fuzz") still attached
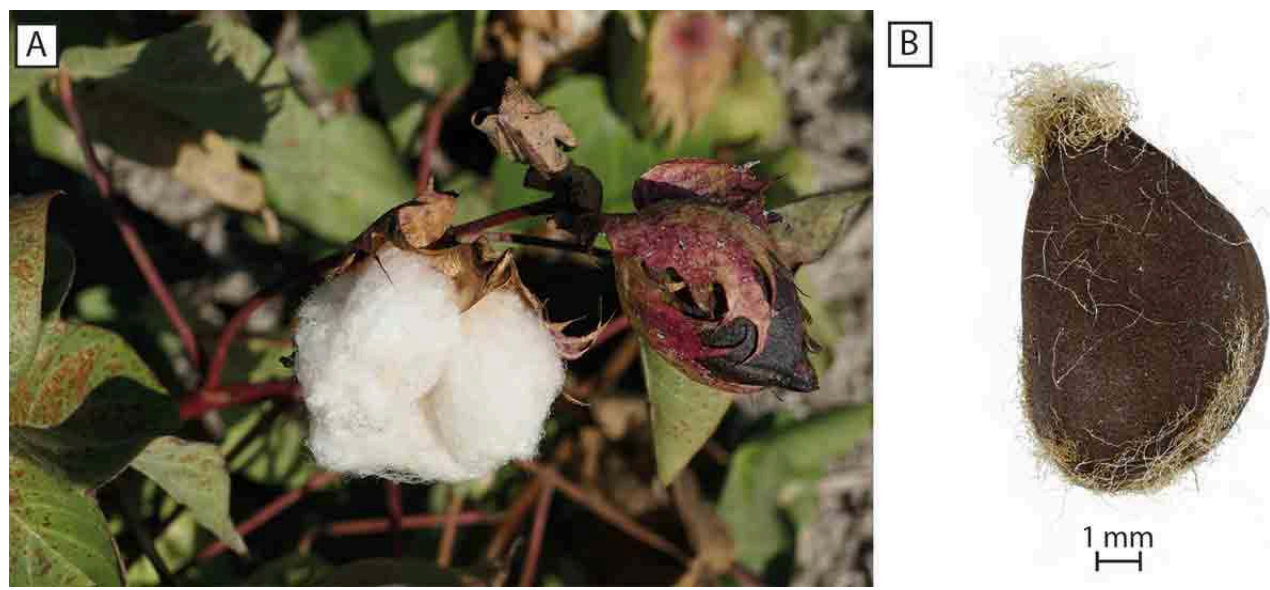

Photos C. Bouchaud

Regardless of the method used for retrieving fibres, spinning is needed to turn fibre bundles into spun yarns. Vital to textile production, spinning is the prerequisite of weaving and much of the final product depends of the quality and characteristics of the spun yarn itself (thread diameter, strength, solidity, regularity, colour, softness, etc.). Spinning consists of pulling a certain amount of fibre together and simultaneously twisting it, constantly repeating the action until a length of yarn is created. Modern and archaeological examples show the occurrence of different cotton spinning methods. In pre-industrial societies, spinning was mostly done by hand with the help of a rudimentary tool: the spindle and its spindle whorl (Barber 1992: 39-77). The spindle whorl adds a small weight to the tool, acting as a flywheel to increase the momentum of the spindle in order to maintain a longer and more effective revolution (Wild 1988: 25-29, Yvanez 2016: 155). Spindle whorls can be made of unfired clay, stone, wood, bone, ceramic or potsherds, and are placed at either the top or the bottom of the spindle according to local methods. After spinning, cotton threads can be left in their natural state or dyed. Dyeing represents another highly specialised sphere of the textile chaîne opératoire, involving a high level of knowledge and different - sometimes hard to find and valuable - raw materials (of plant, animal or mineral origin) ${ }^{13}$. Both natural (white to light-brown) yarn and colourful yarn are then ready to be woven ${ }^{14}$ (Figure 5). Figure 5: Warp-weighted loom (A) and two-beam loom (B), presumably used to weave cotton in the areas under study 
A.

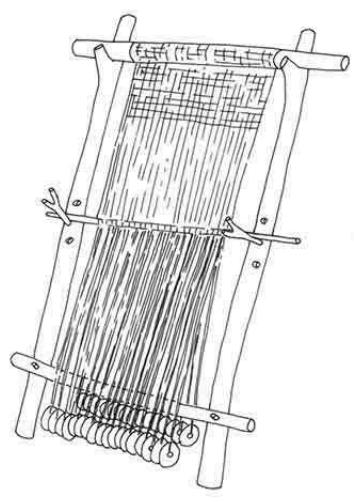

B.

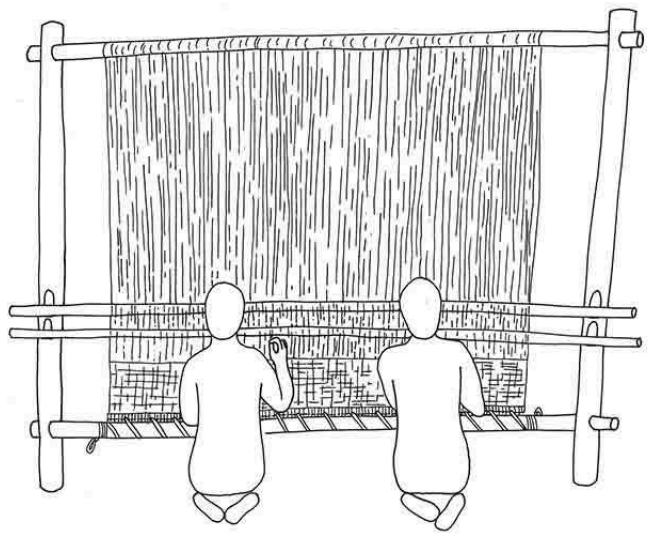

Drawing A. Jeppson (c) CTR/A. Jeppson can either be used as such for different purposes or sent for extra enhancements. The whole fabric can be dyed, can receive secondary decorations (such as embroidery for example), or be tailored into a specific shape and piece. These steps are optional and can also be combined. They lead to the creation of widely different textiles, used for clothing, furnishing, accessories or utilitarian uses. As time-consuming as their production was, textiles were submitted to a very long and demanding life: used and reused, they generally finished their existence in rubbish dumps or in funerary contexts, where they could dress, hide or provide comfort to the body of the deceased ${ }^{15}$ (Figure 6 ).

could potentially be exchanged or traded, and therefore integrate another industry (e.g. in a different place). It is also important to note that the whole chaine opératoire did not necessarily take place in the same location, involving the same workers. As ethnological case studies have shown, harvesting, spinning and weaving were often submitted to a gendered division of labour and work organisation (e.g. Smolderen, this volume). Each of these components would influence the economy and social role of cotton.

Beside the valuable fibres, cotton also produces a range of by-products, which past populations also exploited. Cotton seeds are rich in oil and protein, but naturally secrete a substance called gossypol, present in roots, stems, leaves and bracts too, which is toxic to humans and non-ruminant animals. By-products obtained after the harvest (stems, leaves, and bracts) or after ginning (seeds) could have fed small ruminants (sheep and goat mainly) and cattle and camel in less extent (Omer et al. 2008, Suttie 2004: 168). Today, the food industry promotes glandless cotton varieties. To our knowledge, no mechanical or non-chemical process eliminating this toxic compound existed before the $20^{\text {th }}$ century (Trolinder 2009). Apart from food consumption, cotton oil may have been an interesting illuminant, in addition to other more common plant oils (olive, flax, sesame, radish, or castor oil) and animal fats (Bonnéric 2012, Copley et al. 2005, Ertuğ 2000). However, to our knowledge, only the Babylonian Talmud (c. 500 $\mathrm{CE}$ ) indicates the use of cotton seed oil, without specification regarding its function (Decker 2009, see comment in Newman 1932). Another unique reference, noted by the 
agronomist Ibn al-'Awwām, recommends to burn cotton seeds with orange and citrus tree wood, before mixing them with wine lees, to improve lemon tree growth (Ibn al-'Awwām, Kitāb al-filāha 7.32, ed. Clément-Mullet 1866: 301). Cotton stems collected after the harvest of pseudo-annual cottons also constitute an interesting fuel source (D'Hont 1994). Finally, leaves, flowers, seeds and roots were still recently used in Ethiopia for medicinal purposes (Nicholson 1960: 15). According to Prospero Alpini, Egyptian people of the $16^{\text {th }}$ century used the mucilage from the seed to ease fever, stomach pain and cough (Prospero Alpini, De Plantis Aegypti, liber XVIII, ed. De Fenoyl 2007: 70).

Figure 6: Chaîne opératoire of cotton production, from harvest to finished textiles products

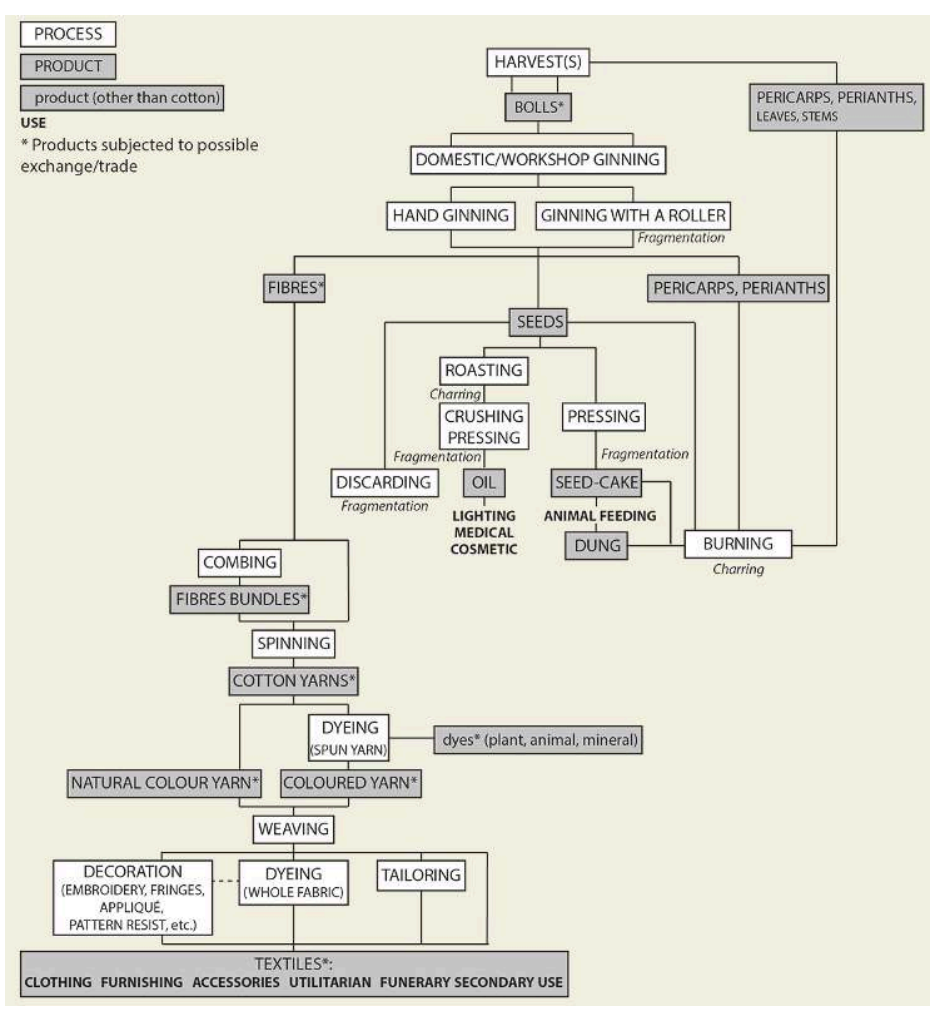

Drawing C. Bouchaud

\section{Inter-disciplinary approach: establishing a dialogue between sources}

The study of archaeological cottons is located at a cross-road between botany and textile studies. A detailed understanding of every level of the chaine opératoire would not be possible without the convergence of different types of expertise, able to analyse the various sources generated by each processes. Following traditional academic fields, archaeobotanists and landscape archaeologists study archaeobotanical remains to reconstruct past ecological and agricultural milieu; textile archaeologists analyse textile fragments, tools and structures pertaining to their production; historians and philologists decode textual or iconographic sources to gage the economic and social value of textile products; while dress historians attempt a synthesis of these last sources to understand ancient garments and fashion (Harlow \& Nosch 2014). 
Each of these sources requires their own analytical methodology and presents specific archaeological challenges. The presence of cotton seeds, spun or unspun fibres, and textiles in archaeological contexts results in specific processing steps of the chaine opératoire, which is now relatively well-known (see above), as well as in various household and commercial activities (through the transport of raw or manufactured cotton). These other two aspects are more difficult to recognise in the archaeological record alone, and not as easy to reconstruct, as their preservation heavily depends on taphonomic processes. Cotton and textile activities are mainly attested by different types of organic materials, such as seeds, fibres, papyri, wooden books, etc., which tend to be destroyed through biological decay (Ballard-Drooker 2001). Hyper-arid climate and/or contexts without much oxygen - such as tombs or waterlogged deposits - allow a partial preservation of organic remains. Elsewhere, most of the findings are preserved because of charring/burning activities. Understanding the biography of each type of cotton artefacts - how they arrived on any given site, were used and finally discarded or abandoned - is the essential first step of our scientific enquiry. By combining and comparing these multidisciplinary results, it becomes possible to then address larger interdisciplinary issues relating to the origin of cotton production and artefacts, or to their economic and social meaning.

\section{Archaeobotanical remains}

\section{How can cotton remains survive through time?}

When the chronological and context parameters are clear, the remains of cotton plant found in archaeological situations are direct proof of the plant's use. With the exception of Qasr Ibrim (Egyptian Nubia), where uncharred complete bolls, raw fibres, and capsules were found (Clapham \& Rowley-Conwy 2009, Yvanez \& Wozniak, this volume), the bulk of archaeobotanical remains is formed by seeds, rarely uncharred and mostly charred, whole or fragmented. Considering the chaîne opératoire described above (Figure 6), several options must be considered to explain their presence. Seeds can be considered as waste products of fibre processing, discarded directly after ginning in dumps (uncharred seeds) or fireplaces (charred seeds). In both cases, the fragmentation of the seed coat might result from the use of a ginning roller, from trampling, and/or from breaking during charring. Seeds and other cotton by-products did represent interesting plant elements, as fodder for ruminants, illuminant and/or fuel. Unfortunately, we do not have any clear evidence of their use in the past. However, we assume that repetitive and high concentrations of broken cotton seeds could reflect one or several of these processes (Bouchaud et al. 2018).

\section{What does archaeological cotton look like?}

The ginned or cleaned seeds are ovoid and somewhat pointed in shape, 7-12 $\mathrm{mm}$ long (Figure 4B). The outer epidermis of the seed coat (or testa), to which are attached the fuzz and lint fibres, presents a longitudinal ridge - the raphe - that ends in a small beak corresponding to the attachment point or the funicle (Figure 7). Under the outermost layers of the seed coat, an inner layer of palisade cells, perpendicular to the seed coat, can be observed. Charring can enhance the visibility of these radially elongated cells and allow the identification of broken archaeological specimens, although confusion with baobab seed coat fragments is possible in regions where both species exist 
(Walshaw 2010). When seeds are fragmented, a small button-like structure (funicular "cap"), corresponding to the diverting point of vascular tissues irrigating the ovule (chalaza), can be observed on the internal surface of the seed coat (Fuller 2008). The embryo, with two well-developed cotyledons, has a smooth and shiny surface, which can become distorted when carbonised because of its rich oil content (Figure 7). The four domestic cotton species have similar seeds, and it remains impossible to distinguish the two old World species from each other only on morphological criteria. To date, only one study has been conducted on the ancient DNA of Old World cottons. The well preserved uncharred cotton seeds found at Qasr Ibrim (Egyptian Nubia) in archaeological layers of the $4^{\text {th }} \mathrm{c}$. CE have been identified as belonging to the $G$. herbaceum species. (Palmer et al. 2012).

Figure 7: Archaeological cotton seeds. Whole (up left) and fragmented (up right and bottom), from Mada'in Salih, Saudi Arabia ( $1^{\text {st- }} 3^{\text {rd }}$ C. CE)

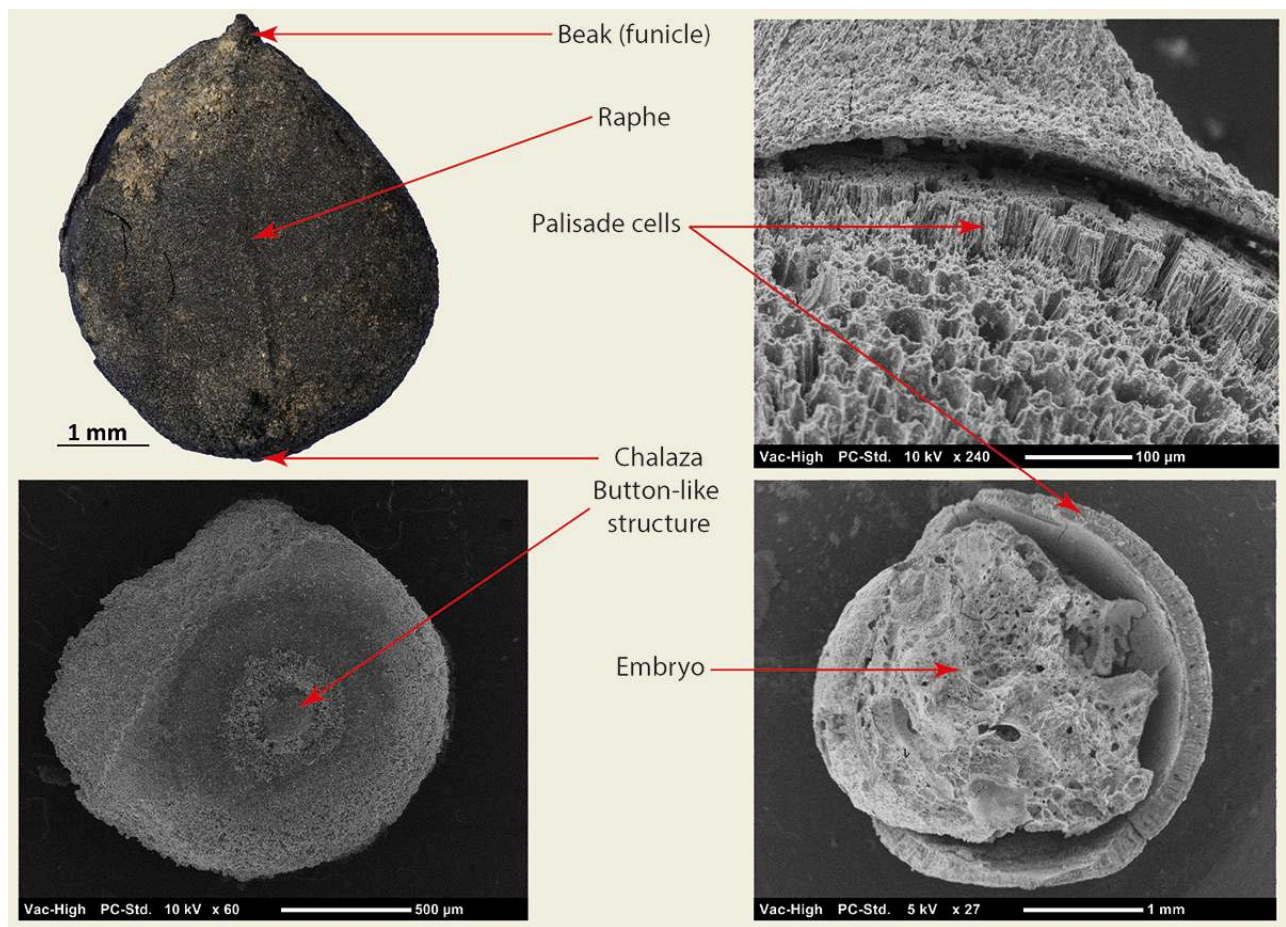

Digital microscope photo C. Bouchaud, SEM photos M. Lemoine, J. Milon.

Cotton wood has yet to be recognised among the macro-botanical assemblages, which is quite surprising in the light of ethnographic and historical sources mentioning the use of stems as fuel in different contexts (see above). Furthermore, cotton wood anatomy is well known and could be easily identified (Bouchaud et al. 2011). On one hand, we must consider that ancient cottons were mostly perennial trees or shrubs, which offered few efficient woody by-products (small branches and stems) comparing to pseudo-annual plants that are completely cut down after the harvest. On the second hand, wood and charcoal analyses are still poorly developed in cotton regions, thus limiting the possibilities of finding such elements. Thirdly, on likely cotton-production sites where charcoal analyses were undertaken, we observe that major woody species such as date palm (Phoenix dactylifera), acacia (Acacia spp.), and capper tree (Capparis decidua), are over-represented and tend to mask potentially secondary woody resources (Madâ'in 
Sâlih, Saudi Arabia: Bouchaud et al. 2012; Indus valley: Lancelotti 2018; Mouweis, Sudan: Bouchaud, work in progress).

\section{Do archaeobotanical finds indicate local production?}

As today, raw cotton circulated in the past, and we have archaeological evidence showing that the ginning process could take place far from the cotton fields (Bouchaud et al. 2011, 2018). The harvest was brought from the field, often stored in individual or collective structures, before being processed ${ }^{16}$. Discovered on the same archaeological site in different location and layers, bolls, wads of raw cotton, empty capsules and recurrent finds of cotton seeds, are the result of diverse fibre preparation phases before spinning. Together, they form a positive argument towards local cotton production, most probably occurring at a short distance from the settlement. However, this "short distance" can have a relative meaning, considering that harvests from different areas could have been centralised in one location for further processing, and thus represent different origins (Bouchaud et al. 2011, 2018). As a result, we must keep in mind that cotton seeds, especially isolated finds, are not direct markers of local cultivation. A network of various evidence must sustain such a hypothesis, in tight connection with a full understanding of is archaeological and historical settings.

\section{Textiles}

It is impossible to consider the history of cotton without considering the history of textiles, as their production constitutes its main motivation and valuable output.

\section{How can cotton textiles survive through time?}

Today as yesterday, textiles are omnipresent in our material surroundings. They clothe and protect our bodies from birth to death, surround us in comfort throughout our environment, provide countless ways to wrap goods, and are an integral part of our transportation modes. Textiles are "surrounding us everywhere"17, fulfilling an extraordinary numbers of functions, both functional and symbolic (Bender Jørgensen 2007). If we add the frequency of their use to their great length of existence, we could expect to find textile remains on archaeological sites as frequently as we find potsherds (Wild 1988: 7). It is of course not the case, since as any organic material, textile fibres are subjected to a high degree of perishability (Ballard-Drooker 2001: 5). In general, we consider that natural textile fibres such as cotton disappear in only 3 weeks if buried in a biologically active soil, at a temperature of $20^{\circ} \mathrm{C}$ or more (Cooke 1990: 5). Mostly composed of cellulose, cotton textiles are an ideal food source for microorganisms, fungi and bacteria, responsible for fibre degradation (Timar-Balazsy \& Eastop 1998, Levin \& Pearce 1998). Hygroscopic in nature, they are also heavily influenced by the presence of water. Therefore, we easily understand that most of the archaeological discoveries of cotton textiles have been made in hyper-arid climatic conditions. Despite the presumed volume of cotton trading within the Roman Empire, it is striking to contemplate the very low number of cotton fabrics discovered north of the ArabianSahelian belt (Wild 1970: 17-19, Wild et al. 2008, see figure 12). Protected by the very dry sands of the desert, which guaranty a minimal bacterial activity, the greatest numbers 
of archaeological cotton textiles come from Sudan, Egypt, Syria, Israel, and, in a lower proportion, Saudi Arabia and Bahrein (see below).

Consequently, cotton textiles from these different sites are relatively well preserved, if often very fragmentary. They retained an intact woven structure and exhibit many of their construction characteristics (see below). If kept stable, they still show their original suppleness, thickness, and even softness. However, in many cases, the very condition of their preservation - the dry environment - has damaged the fibres: heavily desiccated, cotton threads become brittle and loose much of their initial volume $^{18}$. They can even become completely black, as if carbonised. In this case, they are extremely difficult to manipulate and can easily turn into dust (Figure 8). Their condition is also dependent of their proximity with the body of the deceased: body fluids and different material used during the burial rites can destroy the fibre or make the fabric stiff and matted together (Landi 1998: 33-34).

Figure 8: Examples of carbonised/blacken and well-preserved cotton textiles from Sudan. (A) pile weave fabric from Meroe, c. 50-150 CE (courtesy of the Sudan National Museum), (B) pile weave fabric from Karanog, c. 100-200 CE (courtesy of Penn Museum, image E7511.A1)

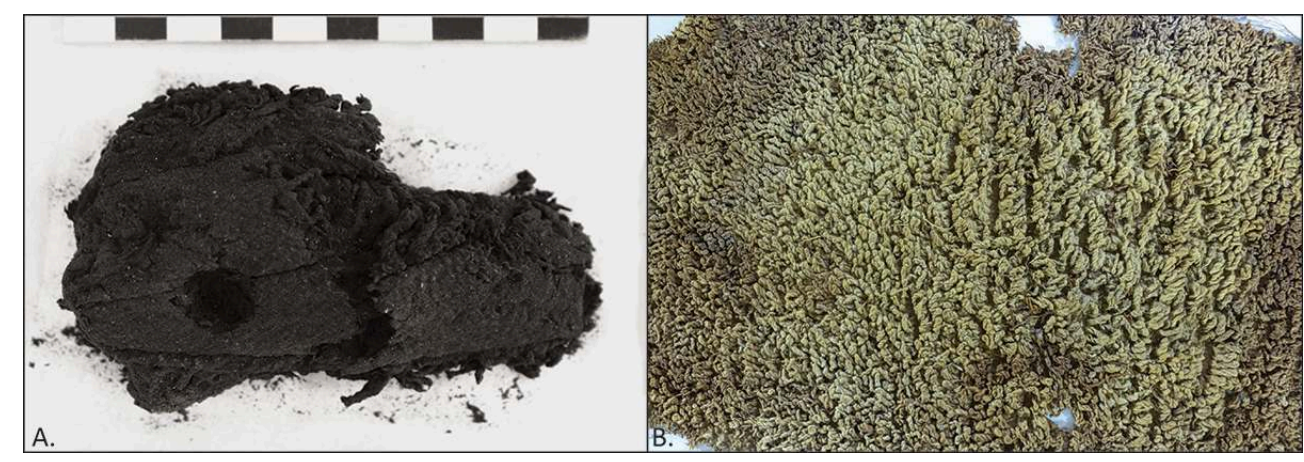

Photos E. Yvanez

As many archaeological textiles, cotton fabrics are most often discovered within funerary contexts. Located away for cultivations and the bustle of city life, the graves tend to be dug in dryer areas, offering a very limited amount of oxygen, and are proportionally less disturbed than urban contexts. This type of setting creates a specific documentary situation: the textile assemblage found in a single grave is not representative of every-day life and consumption but is the result of a conscious selection operated during the funeral. They can be recycled fabrics kept for the construction of the shroud, rags, textile heirlooms placed in the grave as offerings, furnishings, or clothing carefully chosen among the possessions of the deceased. As a result, funerary textiles are a better testimony of funerary rites and display than they are of the general textile production (Carroll \& Wild 2012). Therefore, inferring the place of cotton from a predominantly funerary corpus can only speak of the place cotton textiles occupied during this very special occasion, often in association with a selected population. Comparing this data to other types of sources coming from multiple contexts would be essential to reach a more complete understanding of the role played by cotton fibres in the whole textile industry. 


\section{What do cotton textiles look like?}

Fibre identification is the first question asked during the analysis of a textile, as the answer has important repercussions on the conservation of the artefact and understanding of the piece's production. Several tests exist to identify the nature of textile fibres (Landi 1998: 49-50), from simple naked-eye observations to the use of sophisticated Scanning Electron Microscopes. If well preserved, cotton fibres are easy to identify among the other plant and animal fibres used in Antiquity. Made of short fibres, cotton threads often exhibit a fuzzy surface, formed by the extremities of fibres sticking out of the main twist and wearing off through time and use. Our own experience has shown that well-preserved cotton fabrics are still subtle and soft to the touch, with easy-to-spot fuzz. A hand-help microscope with low magnification (such as a Dino-Lite with 20x - 220x magnification) can usefully supplement these preliminary observations and help in perceiving the diagnostic features of cotton fibres. Cotton fibres are formed by a relatively large and empty lumen, with thin cell walls. When the fibres dry, the walls collapse and twist, producing the characteristic shape of cotton fibres: a bean-shape section and a longitudinal profile with several twists. The fibrils are positioned according to a spiral movement (at $20^{\circ}-40^{\circ}$ angle from the fibre's axis), perceptible even with low magnification, as the fibres take the form of a twisted ribbon (Landi 1998: 21, Rast-Eicher 2016) (Figure 9).

Figure 9: View of ancient cotton fibre and thread from Mada'in Salih (Saudi Arabia), $1^{\text {st }} 3^{\text {rd }}$ c. CE (50432_T32). Thread from a tabby fragment, tomb IGN 97 . Study in progress (P. Dal-Prà)

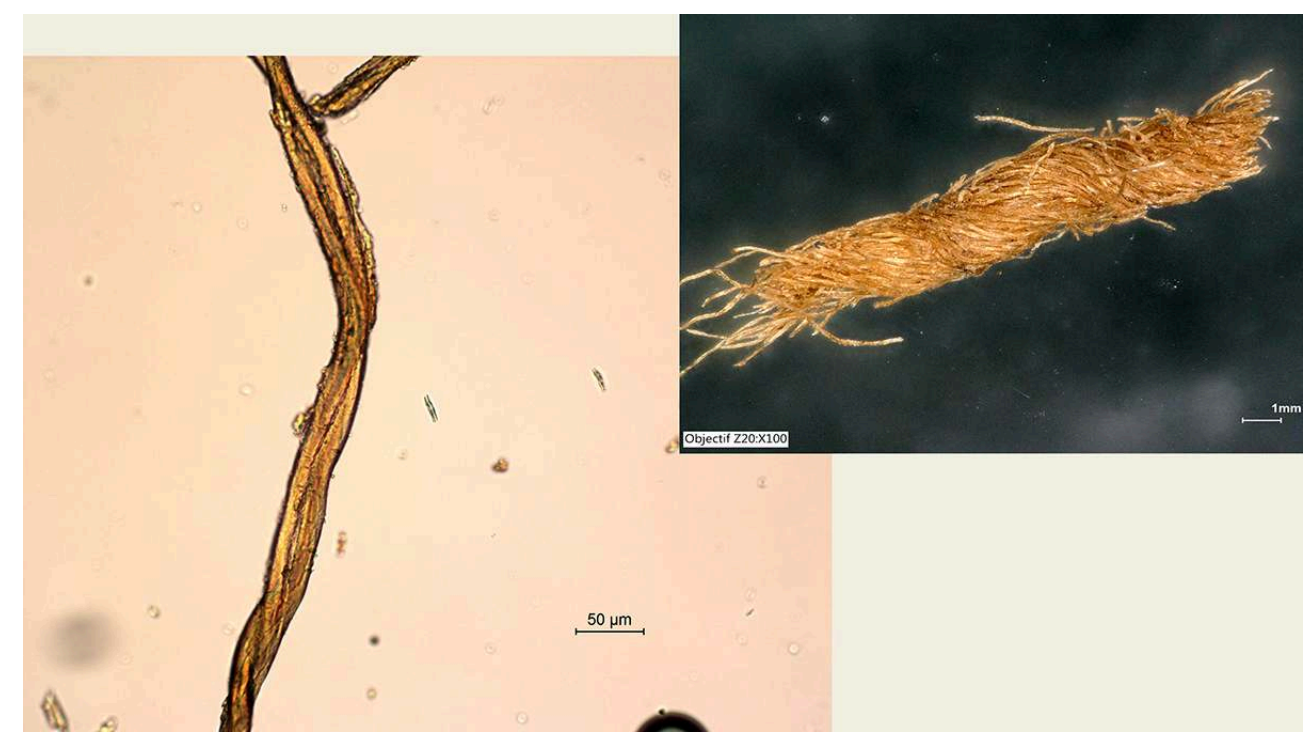

Photo P. Dal-Prà, Institut National du Patrimoine, LRMH @ Archaeological mission of Mada'in Salih

Beside the specificities induced by the use of cotton fibres, the textiles do not greatly differ from the rest of the contemporary textile production. Taking the greater Mediterranean basin as an example (Letellier-Willemin, Shamir, Yvanez \& Wozniak, this volume), it appears that cotton textiles share many of their characteristics with the woollen ones. They are presumably woven on the same looms, often vertical two-beam or warp-weighted looms, most often in a tabby technique, and exhibit strong starting borders and reinforced selvedges ${ }^{19}$. As any textiles, cotton fabrics are defined by their spin direction, weave (type and density), and by technical and decorative details. Each 
of these parameters can vary depending on textile traditions, and their combination forms a sort of "identity card" for the local production. Combined with contextual data, the textiles' features participate in shaping a synthetic picture of the textile industry and its role in society (Andersson Strand et al. 2010: 153).

If sufficiently homogenous, this picture can easily be used to differentiate local vs. extraneous textiles. Indeed, literary sources as well as archaeological finds have long indicated the existence of a well-developed textile trade in Antiquity, in which cotton seemed to have played a significant role (Harlow \& Nosch 2014: 16-19). Relatively small and light, sometimes made with precious material (expensive dyed yarn, silk, golden thread, delicate and time-consuming décors...), high-end textiles were prime candidates for long-distance trade (Thomas 2017). These luxurious fabrics can visibly stand out from the rest of the production, if the characteristics of the last are well defined and homogenous. But in the melting pot of Late Antiquity, where raw material, finished products, stylistics influences and craft know-hows travelled freely, such a clear-cut distinction is rarely possible and can lead to methodological mistakes. The debate over the spin-direction of cotton textiles and their alleged origin is a case in point.

\section{Can cotton spinning in itself indicate the provenance of a textile?}

One of the defining characteristics of an archaeological textile is the direction of twist visible in the yarns from which it was woven. For clarity's sake twist direction is designated by letters, either $\mathrm{Z}$ or $\mathrm{S}$ : the central stroke of the letter corresponds to the direction in which the fibres making up the yarn have been twisted (Figure 10). Z-twist can also be described as 'right-hand' or 'clockwise' twist, S-twist as 'left-hand' or 'anticlockwise' twist.

Figure 10: Diagrams of Z- and S- twist
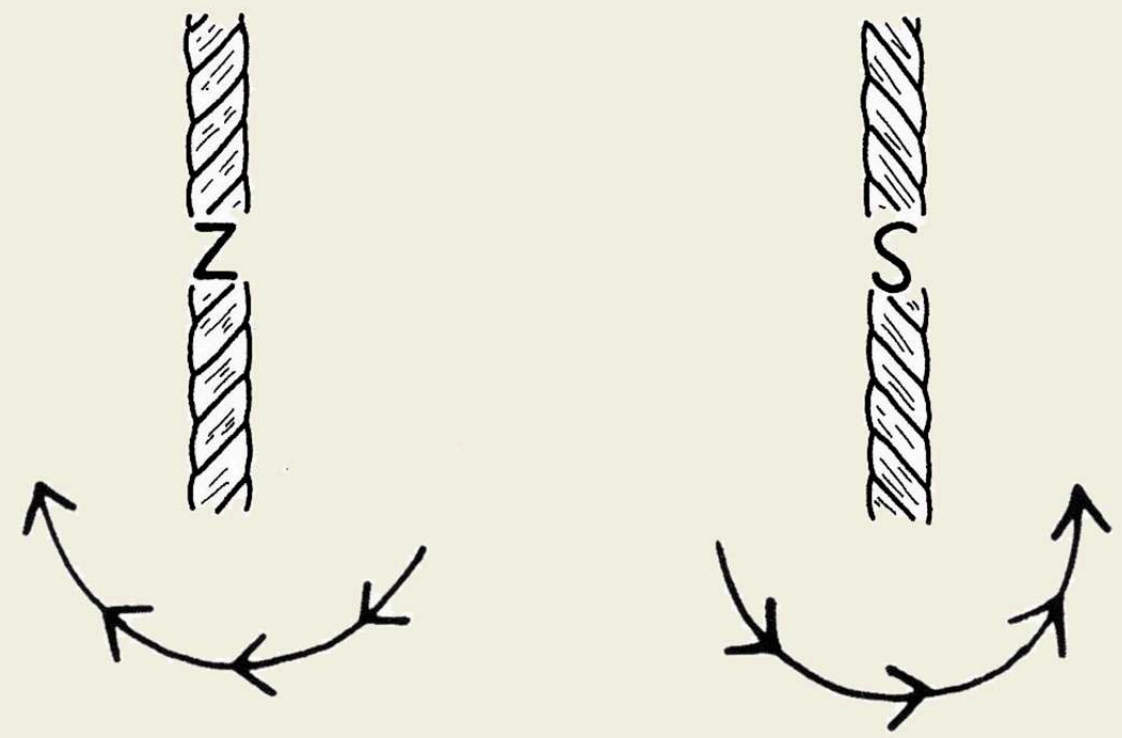

Drawing J.P. Wild 
At Berenike, a Roman port on the Red Sea coast of Egypt, two apparently distinct groups of cotton textiles have been excavated, the one containing exclusively Z-spun yarns, the other S-spun yarns. In the first-century rubbish dumps, $94 \%$ of the cotton finds had Z-spun yarn, but only $6 \%$ S-spun. In the late Roman deposits by contrast, $46 \%$ of the cottons were of Z-spun yarn, 54\% of S-spun (Wild \& Wild 1996: 246, 251, Wild \& Wild 1998: 230). Since S-twist was characteristic of all types of yarn spun in the Nile Valley throughout antiquity, it could be argued that Z-twist pointed to yarns and textiles that were culturally intrusive. There is now strong circumstantial evidence that a community of Indian sailors, engaged in the brisk Indian Ocean trade between the Roman Empire and India, was resident at Berenike (Cappers 2006: 111-117, 216, 225, fig. 4.58, Sidebotham 2011: 69-75, 224-240), and that while some of the cotton fabrics with Z-spun yarns may have been trade goods, others were the personal possessions of resident Indians (Wild 2013). For the S-spun cottons there are two possible sources: on the Upper Nile in Lower Nubia (Wild \& Wild 2014, Yvanez \& Wozniak, this volume) and in the oases of Egypt's Western Desert (Bagnall 2008, Livingstone 2007, Livingstone 2009, Letellier-Willemin, this volume), where the local industry may be derived from Nubia anyway (Clapham \& Rowley-Conwy 2009: 252-253). The characteristics of the Sspun cottons at Berenike, leaving spin direction aside, do not enable us to make a clear choice at present.

Berenike may be a special case where it is relatively safe to treat spin direction as a guide to origin: lines of supply to the port were few and attenuated (Sidebotham 2011). For sites with easier access and a wider choice of textiles, the situation is far less clearcut. The Z-spun, often dyed, wool yarns incorporated into basically S-spun wool textiles on Roman sites elsewhere in Egypt are again intrusive, but their origins are much debated (Cardon et al. 2011: 305, 311-312, Table 1). In sum: spin direction can be a useful 
tool in the argument about textile origins, but must be applied with great caution and only when the wider context is well known.

Neither archaeobotanical and textile remains nor spinning direction are, in themselves, sufficient arguments to determine the origin of cotton. In the past decade, new archaeological methods and mobility studies have been developed to assess the local or non-local origin of the studied material, using the strontium (Sr) isotope composition of human, faunal tooth enamel or botanical material (see for instance Bogaard et al. 2014). This scientific method is based on the fact that the nature and the age of the geological substrate largely influence the isotopic ratio of strontium $\left({ }^{87} \mathrm{Sr} /{ }^{86} \mathrm{Sr}\right)$ in plants, herbivores and humans consuming animals and plant products. Any given plant absorbs these isotopic elements from the substrate while growing, and their ratio is preserved in archaeological remains. Measuring this ratio and matching it with a preestablish database of strontium concentration in the region under study potentially allow for the geo-localisation of the plant's growth. The few studies specifically carried out on charred or uncharred archaeological seeds (Benson 2012) or textiles (Frei 2014) show the strong potential of this method, which offers a new path to be explored to directly evaluate the origin of cotton finds.

\section{Possibilities and limitations of secondary sources}

Beside the two direct sources for cotton production that are cotton archaeobotanical remains and textiles, over types of evidence can usefully complement our investigation. Textiles tools, ancient texts and iconographic representations, as well as experimental and ethnographic approaches, are all obvious sources documenting to varying degrees the production and use of cotton. They are highly specific to the culture under study, and may not be available all together for any given geo-historical areas. However, in climates unfavourable to the conservation of organic material, they can form the only available data and present rich information.

\section{Textile implements}

The study of textile implements is the natural pendant of textile analysis: their identification and careful analysis provide crucial information on the different steps of the chaine opératoire. They can be ordered according to production stage: the spinning tools (spindles and spindle whorls), the weaving tools (parts of loom, loom weights and spools, shuttles and bobbins, weft beaters and weaving combs, weaving picks...), and the sewing tools (needles, picks, thimbles). Most often made of wood and so long decayed, ancient looms are difficult to locate in the archaeological record. Many other implements however, especially spindle whorls and loom weights, are common finds during excavations. A growing number of studies are today exploring the potential of this plentiful material (e.g. Andersson Strand \& Nosch 2015). A statistical approach to the distribution of textile tools, accompanied by the study of their archaeological context, can lead to the identification of manufacturing centres, the scale of production, and its meaningful integration into daily or religious life (e.g. Gleba 2008).

Because preserved textile tools are often made of clay, ceramic or stone, they can be the only trace left of past textile production. In the absence of preserved fabric, they bring precious information about different technical processes, such as spinning and weaving. In the case of cotton textiles, the spindle whorls are most valuable documents. 
Following Elizabeth Barber and her pioneering Prehistoric Textiles, the morphology and weight of spindle whorls have been recognised as two important parameters influencing thread production (Barber 1992: 51-52). The underlying theory is that a spindle whorl "must fall within a certain range of weight in order to do a particular job", and consequently, that one would need to use a light spindle whorl to spin short fibres such as cotton (op.cit.: 53). Thus, establishing a typology of preserved spindle whorls, with a statistic repartition of their shape, size and weight, could in theory help inferring the type of fibre used on a given site and the type of thread produced. In our opinion, this approach is ill suited to cotton, as cotton fibres act similarly as shortstaple wool. Many other parameters would also need to be taken into account, such as the diameter and strength of the final yarn (often different from warp to weft), the ply of the spun thread, and the preferences and level of skills of the spinner. On the basis of Bronze Age spindle whorls found in Nichoria (Greece), scholars from the Centre for Textile Research have established a rigorous protocol of experiments in order to reconstruct the technological parameters of ancient wool and linen textiles (Olofsson et al. 2015: 75-87). This research has shown great potential, but such a rigorous approach remains to be tested on old World cottons. For now, the information brought by textile implements can only participate in the characterisation of the textile chaine opératoire in general, and need to be cross-referenced with contemporary cotton finds from the same region.

\section{Textual and iconographic sources}

Textual and iconographic sources are both essential aspects of ancient cotton studies, as they open a door on the tantalising "craftspeople behind the artefacts" (Wild 2007: 2). Depending on their genre and on the identity and purpose of their authors, ancient texts are quite prolix about the textile production of their time: poetry, prose, economic, technical and legal documents paint a vivid image of a busy corpora of ordinary and noble people, master craftsmen, women, children, and tradesperson engaged in textile production, as well as set models of behaviour towards clothing and textile use in general (Harlow \& Nosch 2014: 14-16) ${ }^{20}$. Regarding cotton, agricultural accounts are particularly valuable, as they detail the day-to-day activities and the output of cotton-producing regions such as the oases of Kharga and Dakhla in the western Egyptian desert (Bagnall 2008, see also Gradel et al. 2012). In some cases, as in ancient Mesopotamia (Quillien, this volume), ancient texts are the only attestation of cotton cultivation during the most remote period. In others, the accounts of Arab agronomists and travellers give precious details regarding the nature and logistic organisation of cotton agriculture (Ducène, Yvanez \& Wozniak, this volume). To be relevant, textual analyses must start by the study and identification of cotton-related terminology ${ }^{21}$. What word was used to designate the cotton plant and its products? When and where did it appear? Was it a local or a borrowed term? And, if borrowed, was it always used to strictly designate cotton, or was it subjected to misinterpretation and semantic shifts? All these questions must be addressed to truly assess the significance of a given text in the global history of cotton. Once understood, cotton terms and associated information can be tracked through time and space, making all inscriptions a crucial component of our understanding of old World cotton. While acting as markers of cotton's diffusion and cultivation, they also provide useful reminders of the complexity of its integration in the social fabric. 
In many respects, iconographic sources work in tandem with textual ones: by supplying images of costumes (more rarely furnishings) within their original context of use, they offer a much wider view of the place and role of ancient textiles in society. Statues, painted ceramic, stelae and reliefs showing human figures allow us to "visualise the clothed body" (Harlow \& Nosch 2014: 8); while painted vases and frescoes showing textile production scenes provide invaluable illustrations of the chaine opératoire (e.g. Hugues \& Forest 1984, Rooijakkers 2005). One must not forget that artistic representations carry an inherent bias: images of textiles and garments are very much the incarnation of "an ideal textile life" (Harlow \& Nosch 2014: 8). If iconography brings meaningful information on ancient textiles, its value in the study of cotton remains limited. Indeed, how can we securely identify a garment made of cotton - a specific fibre - in an image? Even with preserved polychromy, the sole use of a white colour cannot suffice to ascertain the material used for the manufacture of a represented fabric. Only the comparison of costume imagery with a well-known body of preserved archaeological textiles can allow the formulation of such hypothesis (Figure 11).

Figure 11: A cotton garment shown on a painted stela? Funerary stela of Meroitic lady and her son (?) (Karanog, Nubia, c. 100-200 CE, Cairo Museum JE40229; reproduced from Wenig 1978: 206, $\mathrm{n}^{\circ} 127$ ) and comparable cotton textile from Gebel Adda (Nubia, c. 100-350 CE, ROM 973.24.3528)

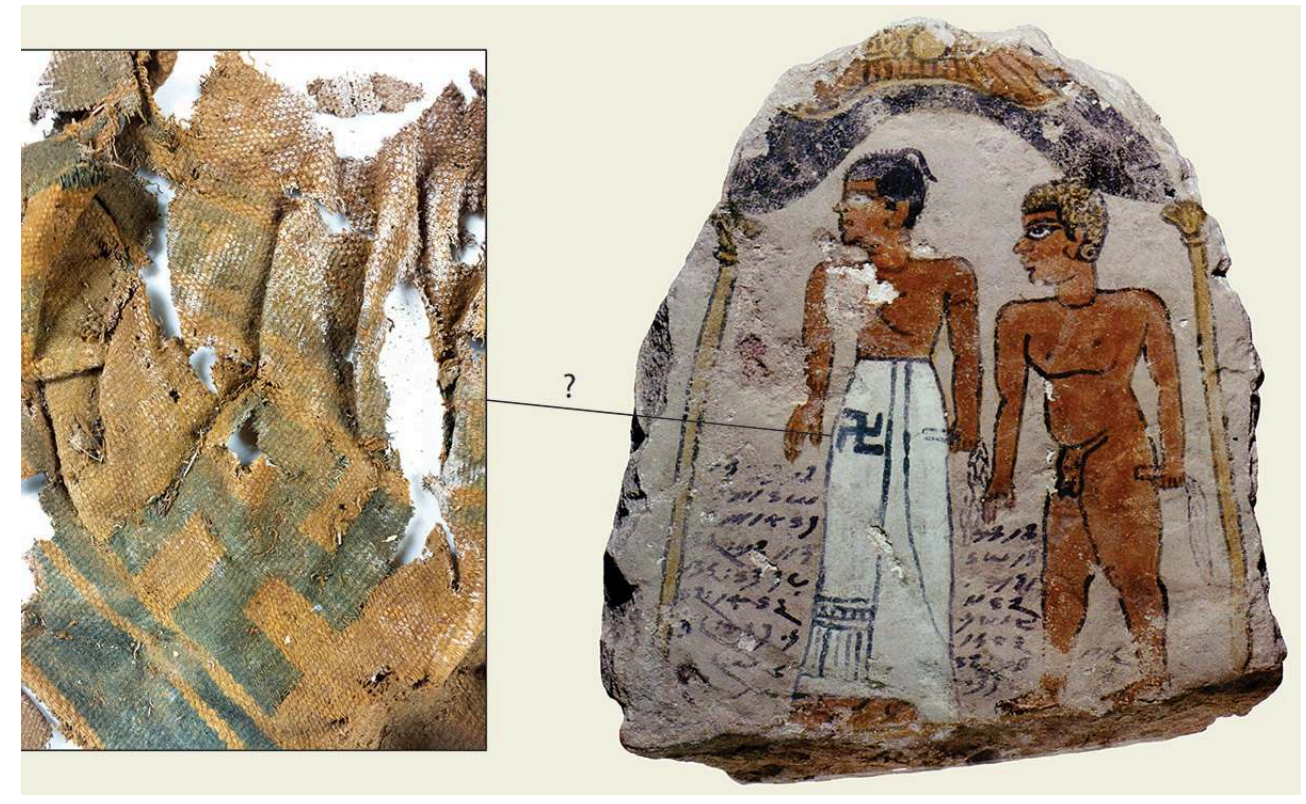

Photo E. Yvanez, with authorisation of the Royal Ontario Museum

Despite their secondary nature and their limitations, both textual and iconographic sources can document areas of past lives that are completely absent from archaeology, such as gender issues or the abstract dimensions of textile experiences. Through their narrative, modern researchers can grasp the feeling of wearing a specific garment, the way it moved through space or its tactile and emotional perception (Barber 2007, Harlow \& Nosch 2014: 12, 22). The study of cotton textiles can also benefit from disciplines such as ethnology and experimental archaeology (Andersson Strand et al. 2010: 163, Harlow \& Nosch 2014: 6). Both offering a direct involvement with textile crafts, they can help in the understanding of specific techniques and tools (see above). Ethnography is also particularly useful in documenting the social context of textile production and use, reminding us of the deep connections between textiles and people. 
"Weaving the social fabric" (Barber 2007), ancient textiles were much more present in everyday life that their current under-representation in the archaeological record may indicate. The article presented in this volume by Lucie Smolderen is an illuminating example of the important role cotton occupied until very recently in the daily life of many populations of Western Africa: beside the time needed for its cultivation, women of every ages dedicated much of their time to its processing and cotton-related activities cemented social bonds between feminine groups and between families.

This inventory shows the potential of each type of sources pertaining to cotton, while highlighting the many issues and questions raised by each type of dataset. Because of their specialisation, each body of knowledge must be carefully built by different experts, many of whom met for the first time at the Paris conference in 2017. In many ways, the present volume illustrates such a multi-disciplinary approach to a single object: cotton. As many of these sources requires expert knowledge and specialised analytical methods (see above), a high-resolution approach focussing on one type of source and /or one aspect of cotton production can be, at this stage, of invaluable importance.

However, as a whole, this volume illustrates the commonality of questions and themes between the different fields: understanding the mechanisms that prevailed in the dissemination of cotton culture is one of them, tracking the geographical origins of plants and textiles is another, among many others. These questions are common to both natural scientists and humanities researchers, across the historical and geographical divides of university fields, and this volume shows the benefit in merging points of view and methods. We wished this volume understandable by all: presenting rigorous botanical results, sound textile analyses, and wide-ranging archaeological and historical issues, in order to open a path towards true inter-disciplinarity. In some cases, because of the state of preservation and the specificities of the area under study, integrating information from different types of artefact and knowledge from different disciplines is simply not possible. In other cases, the available documentation and the continuous collaboration between researchers allow for the first syntheses on the cultivation and use of cotton (Yvanez \& Wozniak, Shamir, this volume). More than layering evidence, we wish to consider cotton within its agricultural, economic and social dynamics as a global development, obeying to both global and local processes. We hope to propose a starting point in the building of a wider and deeper understanding of the fundamental resource that was cotton in the Old World, providing a useful state-of-the-art knowledge and opening new avenues for inter-disciplinary research.

\section{Conclusion: Cotton production in the Old World. State- of-the-art and current research}

Archaeological and historical evidence allow us to have an increasingly accurate view of the various areas of cotton production in the ancient world. Published data, papers presented during the 2017 cotton conference, and the present articles broadly define the following chronological and spatial dispersal (Figure 12). Compiling phylogenetic, archaeogenomic and archaeological data, allows us to hypothesize on the domestication processes of both cotton species, although this issue remains under discussion (Viot, this volume). Cotton (G. arboreum) was probably domesticated 
somewhere in the north-western Indian sub-continent, between the $6^{\text {th }}$ and the $4^{\text {th }}$ mill. $\mathrm{BCE}$, before spreading to the south of the Indian subcontinent from the $3^{\text {rd }}$ mill. BCE onwards (Fuller 2008, Moulhérat et al. 2002). Potentially dated to the same periods, other archaeological evidence of cotton from surrounding regions, such as Jordan (Betts et al. 1994), Caucasus (Kvavadze et al. 2010, Shishlina et al. 2003), and Nubia (Chowdhury \& Buth 1971), constitute isolated discoveries with sometimes insecure contexts (see criticisms in Clapham \& Rowley-Conwy 2009: 249, Fuller 2015: 14, Bouchaud et al. in prep.). Another wave of cotton domestication and diffusion can be dated to the first half of the $1^{\text {st }}$ millennium BCE, notably attested in Mesopotamia (Alvarez-Mon 2010, Muthukumaran 2016). Careful review and re-readings of Akkadian texts and textile discoveries propose a new chronology for the spread of cotton in this region, simultaneously shedding light on its social status and economic value (Quillien, this volume). From the $2^{\text {nd }}$ half of the $1^{\text {st }}$ mill. BCE onwards, several Greek texts indicate that Indian cotton was known and traded in the Mediterranean, suggesting its introduction at Bahrain (Persian Gulf) (Theophrastus, Histori a Plantaru m 4.4.8, ed. Amigues 2010). The earliest archaeological traces of cotton use in north-eastern Africa and Arabia date back to the extreme end of the $1^{\text {st }}$ mill. BCE-beginning of the $1^{\text {st }}$ millennium CE (Bouchaud et al. 2018, in prep., Clapham \& Rowley-Conwy 2009). Shortly after, the volume of relevant finds and documents (seeds, textiles and papyrological texts) soars, dating from the $1^{\text {st }}-2^{\text {nd }} c$. CE onwards. They point to several centres of agricultural production, in Sudan and Nubia, Western Egypt, and north-western Arabia. A complete survey of ancient and recently acquired data shows that Sudan and Nubia played an important role in the development of cotton production and exchange during Antiquity and Medieval periods (Yvanez and Wozniak, this volume). This dynamic process likely involved G. herbaceum, as shown by the unique ancient DNA analysis carried out on cotton finds from Qasr Ibrim in Nubia (Palmer et al. 2012), although Indian cotton ( $G$. arboreum) might have been introduced as well. The hypothesis of the presence of both species is particularly relevant in the Western Egyptian Oases, where very well-preserved textiles exhibit a high diversity of techniques and functions (Letellier-Willemin, this volume), in north-western Arabia (Bouchaud et al. 2018), and in the Levant (Shamir, this volume), which are regions connected to both Indian and African spheres. In north-eastern Africa and Arabia, cotton was likely a perennial shrub or tree, and the oasis environment seems to constitute an effective agrosystems to host this new tropical crop (Bouchaud et al. 2018). The presence of cotton in Central Asia during the $4^{\text {th }}$ C. CE, i.e. in regions suffering from low winter temperatures, probably points to the emergence of new annual forms of the plant (Brite \& Marston 2013). From the $10^{\text {th }} \mathrm{c}$. onwards, Arab medieval literature and technical treaties indicate a slow but continuous progression of cotton in Iranian regions and towards the West, offering the first detailed information on cotton's agronomic requirements (Ducène, this volume). The medieval period saw the expansion of cotton in the greater Mediterranean (Bouchaud 2015, Mazzaoui 1981) and, most significantly, in Western Africa (Champion \& Fuller 2019) where its traditional cultivation is still (barely) visible today. Two important works in this issue focus on these regions and show the social history of cotton and the major changes that took place in its production during the $20^{\text {th }}$ century (Seignobos, Smolderen, this volume). 
Figure 12: Mapping cotton in the Old World. Above: the main cotton production centres with date of first attestation, based on the archaeobotanical, textile, and textual data. Below: geographical areas represented during the cotton conference (2017) and in the present volume

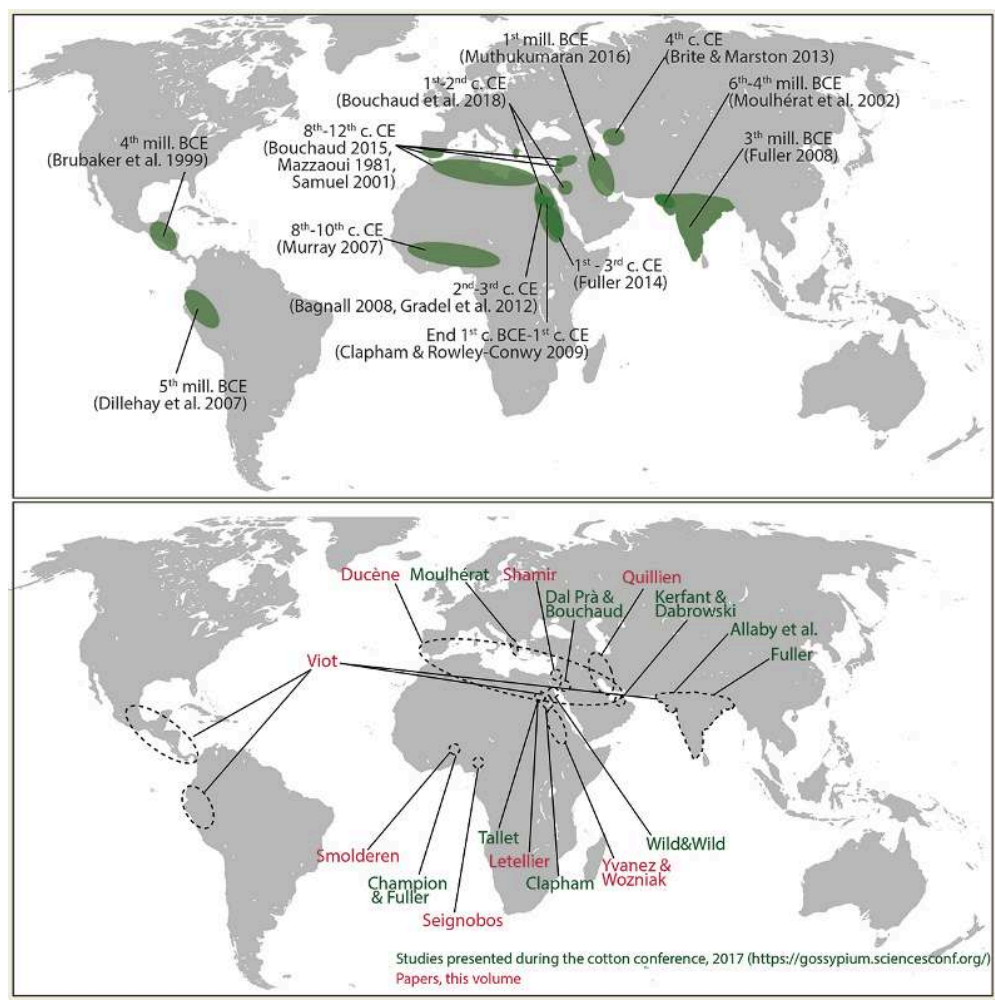

Maps C. Bouchaud

The formidable development of textile studies in the past 15 to 20 years and the multiplication of systematic archaeobotanical studies on ongoing excavations have brought to light many new attestations of cotton textiles. The continuation of our efforts will no doubt bring more results, deepening our understanding of cotton weaving techniques, widening our view of cotton use through the old World, and unveiling interesting exchange and trading patterns. If several details of cotton domestication processes remain a bit unclear, its geographical expansion is now easier to track through time and space. Its botanical definition has also made much progress. Among other issues, a critical reading of this new data and the development of new tools are necessary to improve our knowledge on the chronological and geographical diffusion of cotton. We must be particularly vigilant about the chronological attribution, when the context of discoveries is unclear and/or only based on relative dates, and develop systematic and direct radiocarbon dating of both seeds and textiles (Bouchaud et al. in prep.). We should also remain careful in identifying cotton attestations: more secure seeds (Milon 2018) and fibres (Cao et al. 2009) identification should be reached thanks to the development of new morphometric method; and textual interpretation should be revised through the careful establishment of cotton terminology. Finally, we should continue to enhance interdisciplinary approaches, based on a shared methodological reflection and problematics, and implemented through collaborative tools and events (collaborative database of cotton occurrences, scientific meetings). Together, we can address new questions: What was the value of cotton? Was it an elite production or an everyday commodity? Was cotton used for specific garments and occasions? What was the place of cotton production in the 
everyday life of past populations? Was cotton at the root of a specialised industry, with dedicated workers? What were the modalities of cotton trading in the Old World? Each of these questions demonstrates the fascinating avenues opened in the study of past societies by the merging of environmental and societal issues.

Charlène Bouchaud expresses her gratitude to the Fyssen foundation for awarding her a research grant and the GDRI ATOM "Ancient Textiles from the Orient to the Mediterranean" to finance this project, and thanks Michel Lemoine for his much-valued technical support on the SEM photographs. Elsa Yvanez thanks Eva Andersson Strand and the team at the Centre for Textile Research for sharing their illustrations and, most of all, their knowledge of the textile chaine opératoire. We also thank our colleagues who presented their work during the cotton conference in 2017 and dedicated their time and efforts to the present volume.

\section{BIBLIOGRAPHY}

Abasaeed A.E. 1992 - Briquetting of carbonized cotton stalk. Energy 17 (9): 877-882.

Alvarez-Mon J. 2010 - Textiles and golden bracteates. In : Alvarez-Mon J. (Ed.), The Arjan Tomb: At the Crossroads of the Elamite and Persian Empires. Louvain, Peeters : 30-72.

Amigues S. 2010 - Théophraste. Recherches Sur Les Plantes. Paris, Belin.

Andersson Strand E. 2012 - The textile chaîne opératoire: using a multidisciplinary approach to textile archaeology with a focus on the ancient Near East. Paléorient 38.1-2 : 21-40.

Andersson Strand E., Frei K.M., Gleba M., Mannering U., Nosch M.-L. \& Skals I. 2010 - Old Textiles - New Possibilities. European Journal of Archaeology 13 (2) : 149-173.

Andersson Strand E. \& Nosch M.-L. 2015 - Tools, Textiles and Contexts. Investigating Textile Production in the Aegean and Eastern Mediterranean Bronze Age. Oxford and Philadelphia, Oxbow books. (Ancient Textiles Series ;21).

Bagnall R.S. 2008 - SB 6.9025, cotton and the economy of the Small Oasis. Bulletin of the American Society of Papyrologists $45: 21-30$.

Ballard-Drooker P. 2001 - Material Culture and Perishability. In : Ballard-Drooker P. (Ed.), Fleeting Identities. Perishable Material Culture in Archaeological Research. Carbondale, Southern Illinois University : 3-15. (Center for Archaeological Investigations Occasional Paper ; 28).

Barber E.J.W. 1992 - Prehistoric Textiles. The Development of Cloth in the Neolithic and Bronze Ages. Princeton, Princeton University Press (third printing).

Barber E.J.W. 2007 - Weaving the Social Fabric. In : Andersson Strand E. \& Nosch M.-L. (Ed.), Tools, Textiles and Contexts : 172-178.

Bender Jørgensen L. 1992 - North European Textiles until AD 1000. Aarhus, Aarhus University Press.

Bender Jørgensen L. 2007 - The World According to Textiles. In : Gillis C. \& Nosch M.-L. (Ed.), Ancient Textiles. Production, Craft and Society. Proceedings of the First International Conference on Ancient Textiles. Oxford, Oxbow books : 7-12. 
Benson L.V. 2012 - Development and application of methods used to source prehistoric southwestern maize: a review. Journal of Archaeological Science 39 : 791-807.

Bergman I. 1975 - Late Nubian Textiles, Scandinavian Joint Expedition 8. Oslo, Scandinavian University Books.

Betts A., Van Der Borg K., De Jong A., McClintock C. \& Van Strydonck M. 1994 - Early Cotton in North Arabia. Journal of Archaeological Science 21 (4) : 489-499.

Bogaard A., Henton E., Evans J.A., Twiss K.C., Charles M.P., Vaiglova P. \& Russell N. 2014 Locating Land Use at Neolithic Çatalhöyük, Turkey: The Implications of 87Sr/86Sr Signatures in Plants and Sheep Tooth Sequences. Archaeometry 56 (5) : 860-877.

Bonnéric J. 2012 - Les huiles et leurs usages en terre d'Islam à partir du VIIe s. In : Frère D. \& Hugot L. (Ed.), Les Huiles Parfumées en Méditerranée Occidentale et en Gaule (VIIIe Av. - VIIIe Ap. J.-C.). Rennes, Centre Jean Bérard, Presses universitaires de Rennes : 307-314. (Archéologie de l'artisanat antique ; 6).

Bouchaud C. 2015 - Al quțun : importation des produits et introduction de la culture du coton en Méditerranée occidentale. In : Richarté C., Gayraud R.-P. \& Poisson J.-M. (Ed.), Héritages AraboIslamiques dans l'Europe Méditerranéenne. Paris, Gallimard : 315-331.

Bouchaud C., Tengberg M. \& Dal Prà P. 2011 - Cotton cultivation and textile production in the Arabian Peninsula during antiquity: the evidence from Madâ'in Sâlih (Saudi Arabia) and Qal'at alBahrain (Bahrain). Vegetation History and Archaeobotany 20 : 405-417.

Bouchaud C., Thomas R. \& Tengberg M. 2012 - Optimal use of the date palm (Phoenix dactylifera L.) during Antiquity : Anatomical identification of plant remains from Madâ'in Sâlih (Saudi Arabia). In : Badal E. (Ed.), Wood and Charcoal. Evidences for the Human and Natural History, Saguntum-Extra 13. Valencia, Universitat de Valencia : 173-185.

Bouchaud C., Clapham A., Newton C., Tallet G. \& Thanheiser U. 2018 - Cottoning on to Cotton (Gossypium spp.) in Arabia and Africa during Antiquity. In : Mercuri A.M., D’Andrea A.C., Fornaciari R. \& Höhn A. (Ed.), Plants and People in the African Past: Progress in African Archaeobotany. Cham, Springer International Publishing : 380-426.

Bouchaud C. \& Tallet G. in press - L'intégration du coton au sein des économies agraires antiques : un marqueur discret d'innovation. In : Zurbach J., Lerouxel F. (Ed.), Le Changement dans les Économies Antiques. Bordeaux, Ausonius.

Boulos L. 2000 - Flora of Egypt. Volume 2 (Geraniaceae-Boraginaceae). Cairo, Al Hadara.

Brite E.B. \& Marston J.M. 2013 - Environmental change, agricultural innovation, and the spread of cotton agriculture in the Old World. Journal of Anthropological Archaeology 32 (1) : 39-53.

Brubaker C.L., Bourland F.M. \& Wendel J.F. 1999 - The origin and domestication of cotton. In : Smith C.W. \& Cothren J.T. (Ed.), Cotton: Origin, History, Technology and Production. New York, John Wiley \& Sons : 3-31.

Cao Q., Zhu S., Pan N., Zhu Y. \& Tu H. 2009 - Characterization of Archaeological Cotton (G. herbaceum) Fibers from Yingpan. Technical Briefs in historical archaeology $4: 18-28$.

Cappers R.T.J. 2006 - Roman Foodprints at Berenike: Archaeobotanical Evidence of Subsistence and Trade in the Eastern Desert of Egypt. Los Angeles, Cotsen Institute of Archaeology, University of California.

Cardon D. 2003 - Le monde des teintures naturelles. Belin, Paris. 
Cardon D. 2006 - Chiffons dans le désert : textiles de Maximianon et Krokodilô. In : Cuvigny H. (Ed.), La Route de Myos Hormos. L'armée romaine dans le désert oriental d'Égypte, vol. II, FIFAO 48. Cairo, Institut Français d'Arachéologie Orientale : 619-659.

Cardon D., Granger-Taylor H. \& Nowik W. 2011 - What did they look like? Fragments of clothing found at Didymoi: Case studies. In : Cuvigny H. (Ed.), Didymoi: Une Garnison Romaine dans le Désert Oriental d'Égypte: Praesidia du Désert de Bérénice IV. 1 - Les Fouilles et le Matériel, FIFAO 64. Cairo, Institut Français d'Arachéologie Orientale : 273-362.

Carroll M. \& Wild J.P. (Ed.) 2012 - Dressing the Dead in Classical Antiquity. Gloucestershire, Amberley books.

Champion L. \& Fuller D. 2019 - Archaeobotanical remains. In : Breunig P., Magnavita S. \& Neumann K. (Ed.), Two Thousand Years in Dendi, Northern Benin. Journal of African Archaeology. Leiden, Brill : 216-233. (Monograph Series ; 13).

Chaudhry R.M. \& Guitchounts A. 2003 - Cotton Facts. Washington D.C., Cotton Advisory Committee.

Chowdhury K.A. \& Buth G.M. 1971 - Cotton seeds from the Neolithic in Egyptian Nubia and the origin of Old World cotton. Biological Journal of the Linnean Society 3 (4) : 303-312.

Clapham A. \& Rowley-Conwy P. 2009 - The archaeobotany of cotton (Gossypium sp. L.) in Egypt and Nubia with special reference to Qasr Ibrim, Egyptian Nubia. In : Fairbairn A. \& Weiss E. (Ed.), From Foragers to Farmers. Papers in Honour of Gordon C. Hillman. Oxford, Oxbow Books : 244-253.

Clément-Mullet J.-J. (Ed.) 1866 - Ibn Al-'Awwām. Kitāb al-Filāḥa, Le Livre de l'Agriculture. Paris, Librairie A. Franck.

Cooke B. 1990 - Fibre Damage in Archaeological Textiles. In : O'Connor S. \& Brooks M.M. (Ed.), Archaeological Textiles. Proceedings of the conference 'Textiles for the Archaeological Conservator'. London, Institute for conservation : 5-14. (Institute for Conservation Occasional Paper ; 10).

Copley M.S., Bland H.A., Rose P., Horton M. \& Evershed R.P. 2005 - Gas chromatographic, mass spectrometric and stable carbon isotopic investigations of organic residues of plant oils and animal fats employed as illuminants in archaeological lamps from Egypt. Analyst 130 (6) : 860-871.

Cork C.R., Cooke W.D. \& Wild J.P. 1996 - The use of image analysis to determine yarn twist level in archaeological textiles. Archaeometry 38 (2) : 337-345.

Crowfoot G.M. 1924 - The handspinning of cotton in the Sudan. Sudan Notes and Records 7 (2) : 83-90.

De Fenoyl R. (Ed.) 2007 - Plantes d'Egypte, Par Prosper Alpin, 1581-1584. Cairo, Institut Français d'Arachéologie Orientale. (Voyageurs ; 22).

Decker D. 2009 - Tilling the Hateful Earth: Agricultural Production and Trade in the Late Antique East. Oxford, Oxford University Press.

D’Hont O. 1994 - Vie Quotidienne de'Agedat: Techniques et Occupation de l'espace Sur Le Moyen Euphrate. Damas, Institut Français de Damas.

Dillehay T.D., Rossen J., Andres T.C. \& Williams D.E. 2007 - Preceramic adoption of peanut, squash, and cotton in northern Peru. Science 316, $5833: 1890-1893$.

Ertuğ F. 2000 - Linseed oil and oil mills in central Turkey Flax/Linum and Eruca, important oil plants of Anatolia. Anatolian Studies $50: 171-185$. 
Eyhorn F., Ratter S.G. \& Ramakrishnan M. 2005 - Organic Cotton Crop Guide. A Manual for Practitioners in the Tropics. Frick, Research Institute of Organic Agriculture (FIBL).

Fahd T. (Ed.) 1993 - L'agriculture nabatéenne : traduction en arabe attribuée à Abu Bakr Ahmad b. 'Àli alKasdānī connu sous le nom d'Ibn Waȟ̌iyya (IV/Xe siècle). Damas, Institut Français de Damas.

Fanfani G., Harlow M. \& Nosch M.-L. 2016 (Ed.) - Spinning Fates and the Song of the Loom. The use of textiles, clothing and cloth production as metaphor, symbols and narrative device in Greek and Latin literature. Oxford, Philadelphia, Oxbow books. (Ancient Textile Series ; 24).

Frei K.M. 2014 - Provenance studies of ancient textiles, a new method based on the strontium isotope system. In : Alfaro C., Tellenbach M. \& Ortiz J. (Ed.), Production and trade of textiles and dyes in the Roman Empire and neighbouring regions, Purpureae Vestes IV. Valencia, Universitat de València : 67-72.

Fuller D.Q. 2008 - The spread of textile production and textile crops in India beyond the Harappan zone: an aspect of the emergence of craft specialization and systematic trade. In : Linguistics, archaeology and the human past. Indus Project. Kyoto: Research Institute for Humanity and Nature : 1-26.

Fuller D.Q. 2014 - Agricultural innovation and State Collapse in Meroitic Nubia: the impact of the Savannah Package. In : Stevens C.J., Nixon S., Murray M.A. \& Fuller D.Q. (Ed.), Archaeology of African Plant Use. Walnut Creek, Left Coast Press : 165-177.

Fuller D.Q. 2015 - The economic basis of the Qustul splinter state: cash crops, subsistence shifts, and labour demands in the post-meroitic transition. In : Zach M. (Ed.), Kushite World. Proceedings of the 11th International Conference for Meroitic Studies. Vienna, Verein der Förderer der Sudanforschun : 33-60. (Beitrage zur Sudanforschung Beiheft series).

Gaspa S., Michel C. \& Nosch M.-L. (Ed.) 2017 - Textile Terminologies from the Orient to the Mediterranean and Europe, 1000 BC to 1000 AD. Lincoln, Zea books.

Gillis C. \& Nosch M.-L. 2007 - First Aid for the Excavation of Archaeological Textiles. Centre for Textile Research - Oxford, Oxbow books.

Gleba M. 2008 - Textile Production in Pre-Roman Italy. Oxford, Oxbow books. (Ancient Textile Series ; 4).

Gomes R.S., Wilson P.N., Coates W.E. \& Fox R.W. 1997 - Cotton (Gossypium) plant residue for industrial fuel: An economic assessment. Industrial Crops and Products 7 (1) : 1-8.

Gradel C., Letellin-Willmein F. \& Tallet G. 2012 - "Une laine bien plus douce que celle des moutons" à El-Deir (oasis de Kharga, Égypte) : le coton au cœur de l'économie oasienne à l'époque romaine. In: Guédon S. (Ed.), Entre Égypte et Afrique : relations et échanges entre les espaces au sud de la Méditerranée à l'époque romaine. Bordeaux, Ausonius : 119-141.

Granger-Taylor H. 1998 - Evidence for linen yarn preparation in Ancient Egypt - the hanks of fibre strips and the balls of unprepared rove from Lahun in the Petrie Museum of Egyptian Archaeology, University College London (UC 7421, 7509 and 7510). In : Quirke S. (Ed.), Lahun Studies. Reigate, SIA publications : 103-111.

Grayson A.K. \& Novotny J.R. (Ed.) 2012 - The royal inscriptions of Sennacherib, king of Assyria, 704-681 $B C$. Part 1. Winona Lake, Eisenbrauns.

Harlow M. \& Nosch M.-L. 2014 - Weaving the threads: methodologies in textile and dress research for the Greek and Roman worl - the state of the art and the case for cross-disciplinarity. In : Harlow M. \& Nosch M.-L. (Ed.), Greek and Roman Textiles and Dress, an Interdisciplinary Anthology. Oxford and Philadelphia, Oxbow books : 1-33. (Ancient Textiles Series ; 19). 
Hughes M. \& Forrest M. 1984 - How the Greeks and Romans made cloths. Cambridge, Cambridge University Press. (Classical Studies ; 13-16).

Kvavadze E., Narimanishvili G. \& Bitadze G. 2010 - Fibres of Linum (flax), Gossypium (cotton) and animal wool as non-pollen palynomorphs in the late Bronze Age burials of Saphar-Kharaba, southern Georgia. Vegetation History and Archaeobotany 19 : 479-494.

Lancelotti C. 2018 - 'Not all that burns is wood'. A social perspective on fuel exploitation and use during the Indus urban period (2600-1900 BC). PLOS ONE 13 (3), e0192364 [https://doi.org/ 10.1371/journal.pone.0192364]

Landi S. 1998 - The Textile Conservator's Manual. London, New York, Butterworth Heinemann (Second edition).

Leroi-Gourhan A. 1971 - L'homme et La Matière. Paris, Albin Michel.

Levin M. \& Pearce E.M. (Ed.) 1998 - Handbook of Fiber Chemistry (2nd edition). New York, Marcel Dekker.

Livingstone R. 2007 - The textiles from Kellis, a Roman-period village in Egypt. Archaeological Textiles Newsletter $44: 20-21$.

Livingstone R. 2009 - Late antique household textiles from the village of Kellis in the Dakhleh Oasis. In : De Moor A. \& Fluck C. (Ed.), Clothing the House. Furnishing Textiles of the 1st Millennium AD from Egypt and Neighbouring Countries: Proceedings of the 5th Conference of the Research Group 'Textiles from the Nile Valley', Antwerp, 6-7 October 2007. Tielt, Lanoo : 73-85.

Mazzaoui M.F. 1981 - The Italian Cotton Industry in the Later Middle Ages, 1100-1600. Cambridge, Cambridge University Press.

Michel C. \& Nosch M.-L. (Ed.) 2010 - Textiles Terminologies in the Ancient Near East and the Mediterranean from the $3 r d$ to the First Millennia BC. Oxford and Oakville, Oxbow books. (Ancient Textile Series ; 8).

Milon J. 2018 - Caractérisation taxonomique des cotons (Gossypium spp.) par analyses morphologique et morphométrique des graines. Approche exploratoire et applications archéologiques. Unpublished Master Thesis, Paris, Muséum national d'histoire naturelle.

Moulhérat C., Tengberg M., Haquet J.F. \& Mille B. 2002 - First evidence of cotton at Neolithic Mehrgarh, Pakistan: Analysis of mineralized fibres from a copper bead. Journal of Archaeological Science 29 : 1393-1401.

Muhammad Hamidullah (Ed.) 1973 - Le Dictionnaire Botanique d'Abū Hanīfa Ad-Dīnawarī (Kitāb anNabāt). Reconstitué d'après Les Citations Des Ouvrages Postérieurs. Cairo, Institut Français d'Archéologie Orientale.

Murray A. 2007 - Medieval cotton and wheat finds in the Middle Niger Delta (Mali). In : Capper R.T.J. (Ed.), Fields of Change. Proceedings of the 4th International Workshop for African Archaeobotany. Groningen, Barkhuis \& Groningen University Library : 43-51.

Muthukumaran S. 2016 - Tree cotton (G. arboreum) in Babylonia. In : Foietta E., Ferrandi C., Quirico E., Giusto F., Mortarini M., Bruno J. \& Somma L. (Ed.), Cultural and Material Contacts in the Ancient Near East. Proceedings of the International Workshop 1-2 December 2014, Torino. Sesto Fiorentino, Apice libri : 98-105.

Newman R.J. 1932 - The Agricultural Life of the Jews in Babylonia between the Years 200 C.E. and 500 C.E. London, Oxford University Press. 
Nicholson G.E. 1960 - The production, history, uses and relationships of cotton (Gossypium spp.) in Ethiopia. Economic Botany 14 (1) : 3-36.

Omer S.A., Agab H., Samad H.A. \& Turki I.Y. 2008 - Effect of feed type on some blood constituents of Sudanese growing camel (Camelus dromedarius) calves. The Sudan Journal of Veterinary Science and Animal Husbandry 47 (2) : 107-116.

Olofsson I., Andersson Strand E. \& Nosch M.-L. 2015 - Experimental testing of Bronze Age textile tools. In : Andersson Strand E. \& Nosch M.-L. (Ed.), Tools, Textiles and Contexts : 75-100.

Orsenna E. 2006 - Voyage au pays du coton. Petit précis de mondialisation. Paris, Le livre de Poche, Fayard.

Page J.T., Huynh M.D., Liechty Z.S., Grupp K., Stelly D., Hulse A.M., Ashrafi H., Van Deynze A., Wendel J.F. \& Udall J.A. 2013 - Insights into the evolution of cotton diploids and polyploids from whole-genome re-sequencing. G3: Genes, Genomes, Genetics 3 (10) : 1809-1818.

Palmer S.A., Clapham A.J., Rose P., Freitas F.O., Owen B.D., Beresford-Jones D., Moore J.D., Kitchen J.L. \& Allaby R.G. 2012 - Archaeogenomic Evidence of Punctuated Genome Evolution in Gossypium. Molecular Biology and Evolution 29 (8) : 2031-2038.

Pfister R. \& Bellinger L. 1945 - The Excavations at Dura-Europos. Final Report IV. Part II: The Textiles. New Haven, Yale University Press.

Rast-Eicher A. 2016 - Fibres. Microscopy of Archaeological Textiles and Furs. Budapest, Archaeolingua.

Reis D., Vian B. \& Bajon C. 2006 - Le Monde Des Fibres. Paris, Belin.

Rooijakkers T. 2005 - Unravelling Beni Hassan. Archaeological Textiles Newsletter 41 : 2-13.

Samuel D. 2001 - Archaeobotanical evidence and analysis. In : Berthier S. (Ed.), Peuplement rural et aménagements hydroagricoles dans la moyenne vallée de l'Euphrate fin VIIe-XIXe siècle. Damas, Institut français d'études arabes de Damas : 343-48.

Shishlina N.I., Orfinskaya O.V. \& Golikov V.P. 2003 - Bronze Age textiles from the North Caucasus: new evidence of fourth millennium BC fibres and fabrics. Oxford journal of archaeology 22 (4) :

331-344.

Sidebotham S.E. 2011 - Berenike and the Ancient Maritime Spice Route. Berkeley and Los Angeles, The University of California Press.

Smith C.W. \& Cothren J.T. 1999 - Cotton: Origin, History, Technology and Production. New York, John Wiley \& Sons.

Stephens S.G. 1976 - Some observations on photoperiodism and the development of annual forms of domesticated cottons. Economic Botany 30 (4) : 409-418.

Suttie J.M. 2004 - Conservation Du Foin et de La Paille Pour Les Petits Paysans et Les Pasteurs. Rome, Organisation des Nations Unies pour l'alimentation et l'agriculture. (Collection FAO, Production végétale et protection des plantes ; 29).

Timar-Balazsy A. \& Eastop D. 1998 - Chemical Principles of Textile Conservation. London, Betterworth-Heinemann.

Thomas T.K. 2017 - Perspectives on the wide world of luxury in later Antiquity: silk and other exotic textiles found in Syria and Egypt. In: Hildebrand B. \& Gillis C. (Ed.), Silk. Trade and Exchange along the Silk Roads between Rome and China in Antiquity. Oxford \& Philadelphia, Oxbow books : 51-81. (Ancient Textiles Series ; 29). 
Trolinder E.L. 2009 - Genetic engineering of cotton. In : Paterson A.H. (Ed.), Genetics and Genomics of Cotton, Plant Genetics and Genomics: Crops and Models 3. New York, Springer : 187-207.

Trombert E. 1996 - Une trajectoire d'Ouest en Est sur la Route de la soie. La diffusion du coton dans l'Asie Centrale sinisée (6e-10e siècles). In : La Persia e l'Asia Centrale Da Alessandro al X Secolo (Roma, 9-12 Novembre 1994). Rome, Instituto italiano per il medio ed estremo oriente : 205-227.

Walshaw S.C. 2010 - Converting to rice: urbanization, Islamization and crops on Pemba Island, Tanzania, AD 700-1500. World Archaeology 42 (1) : 137-154.

Wendel J.F. \& Cronn R.C. 2003 - Polyploidy and the evolutionary history of cotton. Advances in Agronomy 78 : 139-186.

Wenig S. 1978 - Africa in Antiquity II. The Arts of Ancient Nubia and the Sudan. The Catalogue. The Brooklyn Museum, New York.

Wild J.P. 1970 - Textile Manufacture in the Northern Provinces. Cambridge, Cambridge University Press.

Wild J.P. 1988 - Textiles in Archaeology. Princes Risborough, Shire Archaeology.

Wild J.P. 2007 - Methodological Introduction. In : Andersson Strand E. \& Nosch M.-L. (Ed.), Tools, Textiles and Contexts : 1-6.

Wild J.P. 2013 - The first Indian carpets - a view from Berenike. In : De Moor A., Fluck C. \& Linscheid P. (Ed.), Drawing the Threads Together. Textiles and Footwear of the First Millennium AD from Egypt: Proceedings of the $7^{\text {th }}$ Conference of the Research Group 'Textiles from the Nile Valley', Antwerp, 7-9 October 2011. Tielt, Lanoo : 74-85.

Wild J.P. \& Wild F. 1996 - The textiles. In : Sidebotham S.E. \& Wendrich W.Z. (Ed.), Berenike 1995: Preliminary Report of the 1995 Excavations at Berenike (Egyptian Red Sea Coast) and the Survey of the Eastern Desert. Leiden, Research School CNWS : 245-256.

Wild J.P. \& Wild F. 1998 - The textiles. In : Sidebotham S.E. \& Wendrich W.Z. (Ed.), Berenike 96: Report of the Excavations at Berenike (Egyptian Red Sea Coast) and the Survey of the Eastern Desert. Leiden, Research School CNWS : 221-236

Wild J.P. \& Wild F. 2014 - New perspectives on the changing textile cultures of Lower Nubia. In : O'Connell E.R. (Ed.), Egypt in the First Millennium AD: Perspectives from New Fieldwork. British Museum Publications on Egypt and the Sudan 2. Louvain, Peeters : 71-85

Wild J.P., Wild F. \& Clapham A.J. 2008 - Roman Cotton Revisited. In : Alfaro C. \& Karali L. (Ed.), Purpurae Vestes II, Vestidos, textiles y tintes: estudios sobre la producción de bienes de consumo en la Antiguedad: actas del II symposium internacional sobre textiles y tintes del Mediterráneo en el mundo antiguo. Valencia, Universitat de València : 145-149.

Yvanez E. 2016 - Spinning in Meroitic Sudan. Textile Production Implements from Abu Geili. Dotawo, a journal for Nubian studies $3: 153-178$.

\section{NOTES}

1. "Walking by, a man notices a shrub, which branches end with white flakes. We can imagine that he reaches his hand out. Humanity has just met with the softness of cotton." 
"To understand globalisations, yesterday's and today's, nothing surpasses the observation of a piece of textile. Without a doubt because it is only made of threads and ties, and of the shuttle's journey." Orsenna 2006: 11-12, 17, English translation proposed by the authors.

2. Charlène Bouchaud and Vladimir Dabrowski (AASPE-UMR 7209, MNHN-CNRS) organised this meeting with financial support from the Fyssen foundation and the GDRI ATOM "Ancient Textiles from the Orient to the Mediterranean".

3. For language convenience, we use the term "Old World" to refer to Asia, Africa and Europe, in contrast with the "New World" (Americas and Oceania).

4. The Royal Inscriptions of the Neo-Assyrian Period 3/1 16 vii 17-21; 17 vii 53-57, in Grayson \& Novotny 2012: 121, 143.

5. Arrian, Indica: 16.1, Herodotus, Histories: 3.106, Pliny the Elder, Naturalis Historia: 12.8, 21-22, Pomponius Mela, De situ orbis: 3.7, Strabo, Geographica: 12.20, Theophrastus, Historia plantarum: 4.4.8. See details and comments in Bouchaud \& Tallet in press

6. "A nomad of the Kalb tribe told me that cotton grew in their country in the form of a tree until it reached the size of the apricot tree and it thus lasted twenty years" (translation proposed by the authors).

7. "In Hejaz, Egypt, Ascalon, Basra (...) it reaches the proportions of a fig tree. In our country, it lives several years during which it supplies cotton" (translation proposed by the authors).

8. "According to Abū' l-Khayr and others, cotton is grown in watered and unwatered soil. According to Ibn Bassal, the soil that, in Spain, is suitable for cotton is rough and arid soil; in both types of soil, the cotton product is early and of great benefit, and it never lags behind in its time (of maturity). There are those who say that cotton likes fresh soil when sown in unwatered soil" (English translation proposed by the authors)

9. Translation proposed by the authors. Original quotation: «Le coton est le porc de la botanique : chez lui, tout est bon à prendre. Donc tout est pris », Orsenna 2006: 15.

10. First developed by prehistorians, this approach has had a great importance in the development of textile studies. For an in-depth analysis of the textile chaine opératoire, see Andersson Strand 2012. For a visual rendition and critical discussion, see Harlow \& Nosch 2014.

11. About the integration of textile production into its wider cultural milieu and its greater implication in the understanding of past societies, see Andersson Strand et al. 2010.

12. André Leroi-Gourhan was one of the first to propose a comprehensive view of the textile chaine opératoire, already linking it to the society that made it possible. According to his classification, woven textiles are "flexible solids" created by two sheds of parallel threads kept in tension by a frame and/or suspension (Leroi Gourhan 1971: 19, 269). Establishing as basic principle that "material conditions technique", he detailed the different stages of the textile chaine opératoire according to the intrinsic qualities of textile fibres and the nature of the technical interventions needed (Leroi Gourhan 1971: 269-296).

13. For a wide and detailed view of natural dyes, with associated dyeing techniques, see Cardon 2003.

14. For an introduction to ancient weaving methods, see Barber 1992.

15. For an example of secondary use in an urban context, see for example Cardon 2006. For examples of textile reuse in funerary context, see for example Bergman 1975.

16. For a modern ethnologic example, see Smolderen, this volume.

17. Bender Jørgensen 2007: 7.

18. For a general description of damages and degradation agents, see Landi 1998: 8-37.

19. For the basics of textiles analyses and recording, see Andersson Strand et al. 2010 and Gillis \& Nosch 2007.

20. For a detailed approach to textile themes in classic literature, see Fanfani et al. 2016. 
21. For a wider understanding of textile terminology and associated fields of research, see Michel \& Nosch 2010 and Gaspa et al. 2017.

\section{AUTHORS}

\section{CHARLĖNE BOUCHAUD}

Archaeozoology, Archaeobotany, Societies, Practices, Environments (AASPE-UMR7209), CNRS, National Museum of Natural History (MNHN) - 55 rue Buffon (CP56) 75005 Paris, France.

ORCiD 0000-0002-1318-027X

charlene.bouchaud@mnhn.fr

\section{ELSA YVANEZ}

Marie Skłodowska Curie fellow, TexMeroe project (European Union, Horizon 2020 research and innovation programme, grant agreement $n^{\circ} 743420$ ).

Centre for Textile Research, University of Copenhagen - Karen Blixens Plads 8, 2300 Copenhagen $\mathrm{S}$, Denmark.

ORCiD 0000-0002-0934-8367

elsa.yvanez@gmail.com

\section{JOHN PETER WILD}

University of Manchester - Honorary Research fellow in Archaeology, University of Manchester, UK.

j.p.wild.58@cantab.net 